UNIVERSIDADE DE SÅO PAULO

INSTITUTO DE GEOCIENCIAS E ASTRONOMIA

\title{
APLICAÇĀO DO MÉTODO ELETRO-MAGNÉTICO INDUTIVO NA PROSPECÇÃO DE MINÉRIO DE COBRE
}

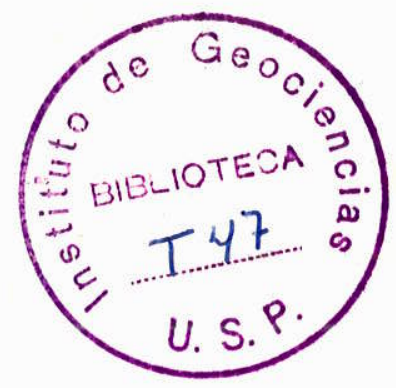

TESE APRESENTADA AO INSTITUTO DE GEOCIENCIAS E ASTRONOMIA DA UNIVERSIDADE DE SÃO PAULO PARA O CONCURSO DE LIVREDOCENCIA NA DISCIPLINA DE GEOFISICA APLICADA

NELSON ELLERT

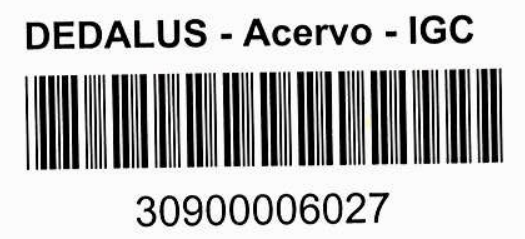




\section{INDICE}

Pāg.

\section{PARTE A}

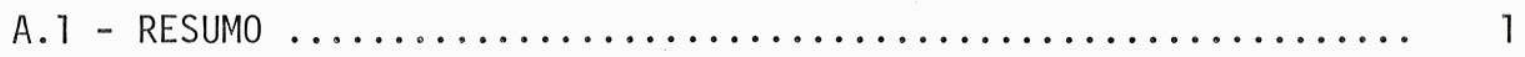

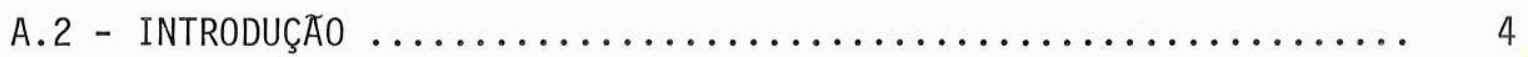

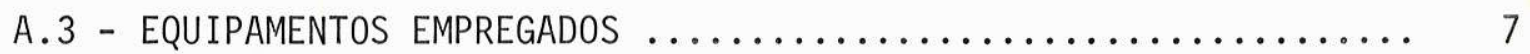

A. 4 - PROCEDIMENTOS DE CAMPO ......................... 11

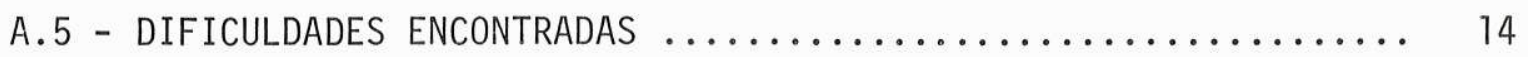

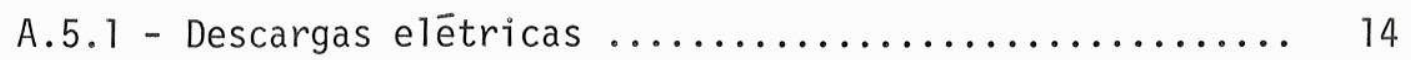

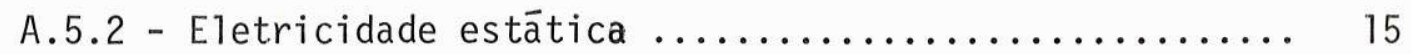

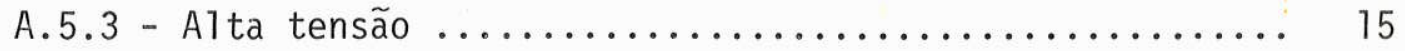

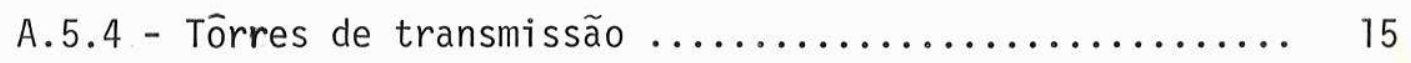

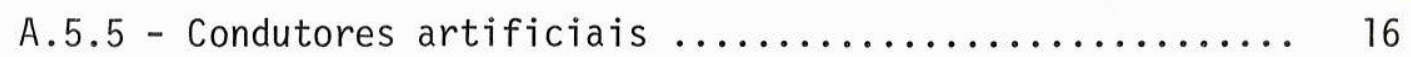

A. 6 - FUndAMENTOS TEÖICOS $\ldots \ldots \ldots \ldots \ldots \ldots \ldots \ldots \ldots \ldots \ldots \ldots \ldots \ldots \ldots \ldots \ldots \ldots$

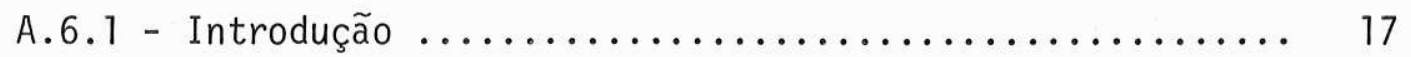

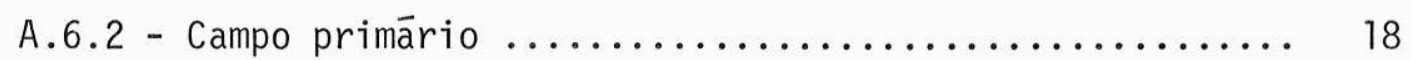

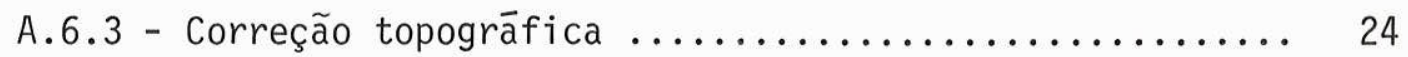

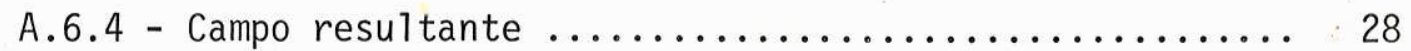

A.7 - EXPERIÊNCIAS EM MODÊLOS REDUZIDOS $\ldots \ldots \ldots \ldots \ldots \ldots \ldots \ldots \ldots \ldots$

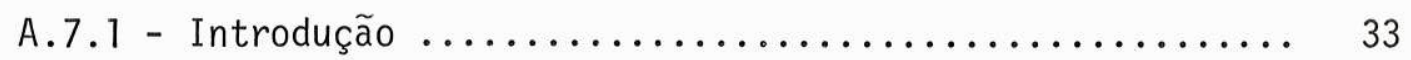

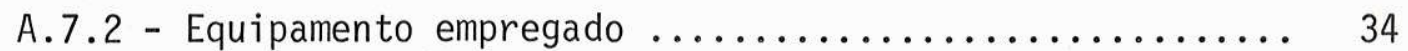

A.7.3 - Resultados obtidos ........................ 37

A.7.3.1 - Dimensionamento dos modêlos .......... 37

A.7.3.2 - Exemplos de curvas obtidas ............. 39

\section{PARTE B}

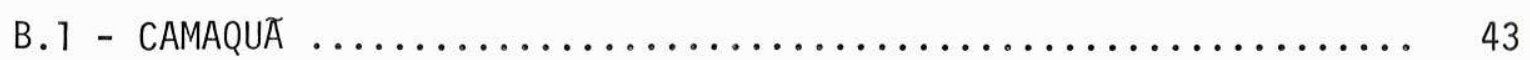

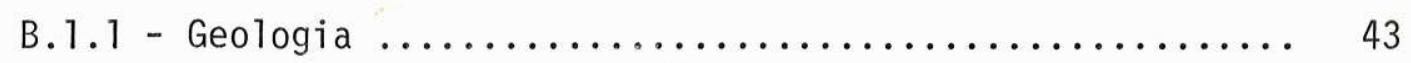


Pāg.

B.1.1.1 - Geologica local .................. 43

B.1.1.2 - Estratigrafia e litologia ........... 44

B.1.1.3 - Mineralização ..................... 45

B.1.1.4 - Gênese da jazida ................. 47

B.1.2 - Geofísica ............................ 48

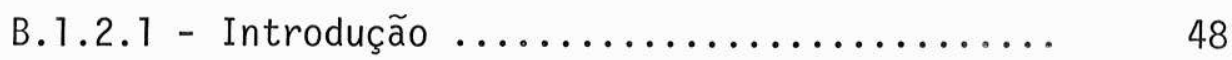

B.1.2.2 - Fase preliminar .................. 49

B.1.2.3 - Fase de prospecção ................. 55

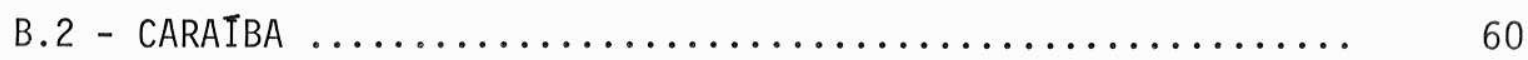

B.2.1 - Geologia ............................... 60

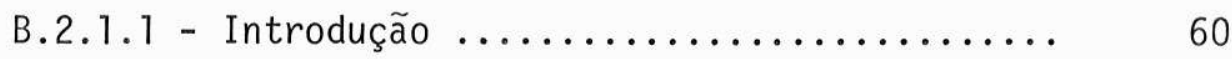

B.2.1.2 - Geologia regional ................. 61

B.2.1.3 - Geologia local ................... 62

B.2.1.4 - Mineralização .................... 63

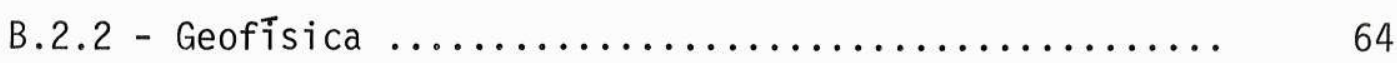

B.2.2.1 - Introdução ...................... 64

B.2.2.2 - Fase preliminar .................. 64

B.2 2.3 - Fase de prospecção $\ldots \ldots \ldots \ldots \ldots \ldots \ldots . .61$

B.2.3 - Aplicação do "trend surface analysis" .......... 85

B.2.3.1 - Introdução ...................... 85

B.2.3.2 - .Cäkulo ........................ 86

B.2.3.3 - Mapa dos resĩduos ................. 86

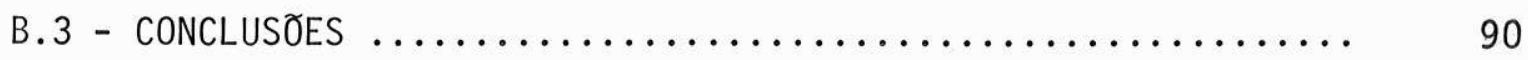

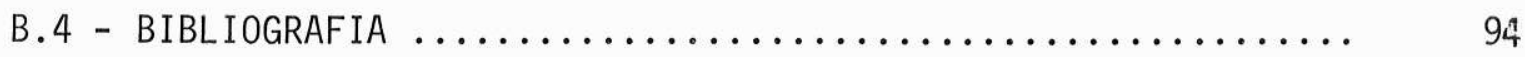


Pāg.

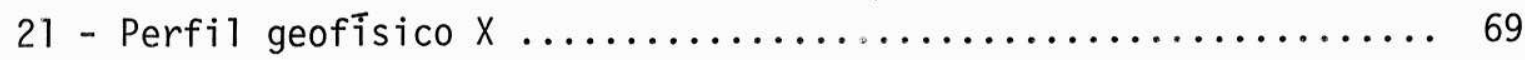

22 - Mapa de isoanomalia geoquímica e posição dos perfis I e II . . . 72

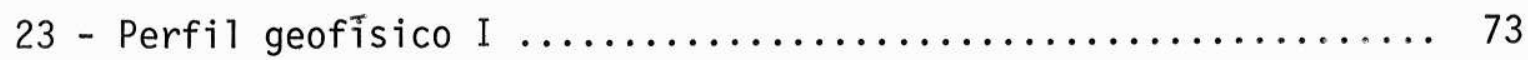

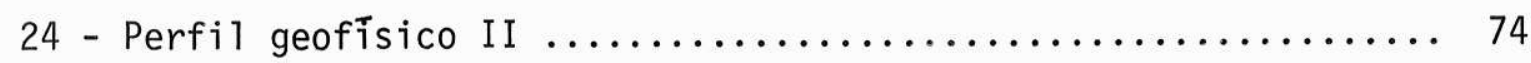

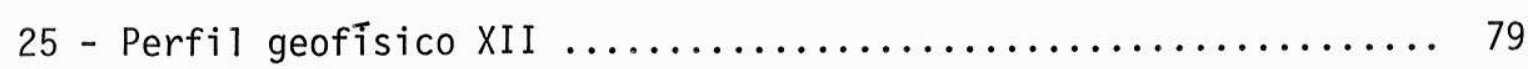

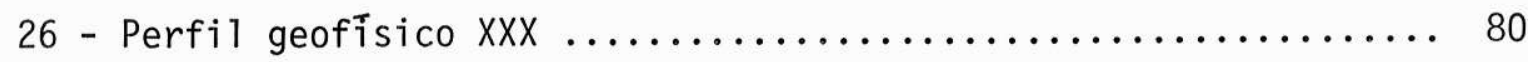

27 - Mapa geoquĩmico regional e delimitação da ārea estudada em por-

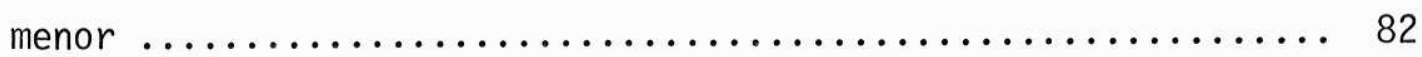

28 - Posição das anomalias e suas grandezas ................. 83

29 - Posição relativa de $\mathrm{R}$ e $\mathrm{T}$ e o corpo condutor ................ 88

30 - Posição das anomalias geofísicas obtidas pela tēcnica da asso -

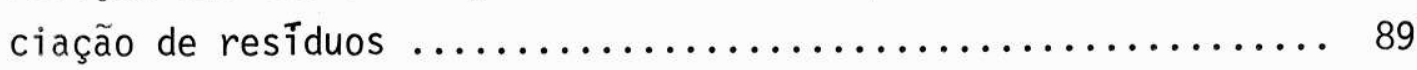




\section{INDICE DE FIGURAS}

№

Pāgs.

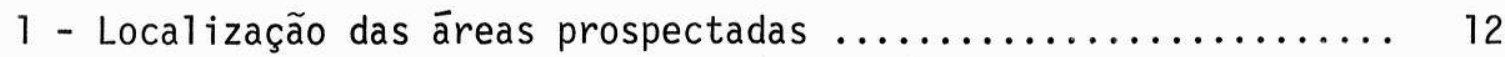

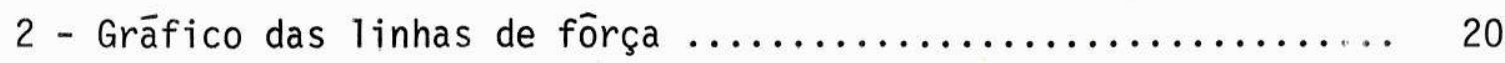

3 - Campo eletro-magnético de um dipolo .................... 24

4 - Grāfico para a correção topogräfica .................... 26

5 - Campos primārio e secundārio .......................... 28

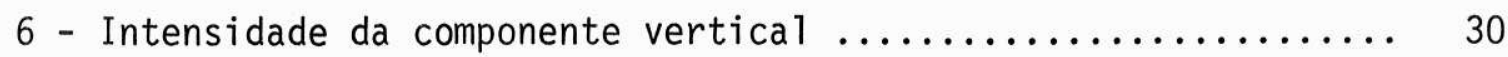

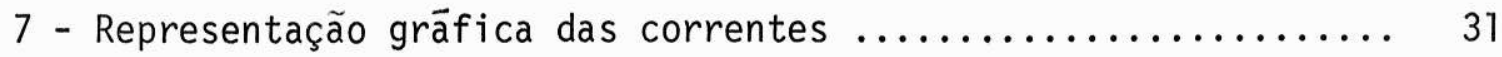

8 - Representação vetorial do movimento harmônico .............. 32

9 - Modêlo vertical em profundidades variadas ................ 39

10 - Corpo vertical, frequências variadas ................... 40

11 - Modêlo com diferentes ângulos de inclinação ............... 41

12 - Perfil I medido sôbre o filão S. Luiz ................... 50

13 - Perfil II medido sôbre o fịão S. Luiz .................. 51

14 - Perfil I medido sôbre o filão 0scarino ................... 53

15 - Perfil II medido sôbre o filão 0scarino .................. 54

16 - Perfil geofísico através do filão Feliciano ................ 58

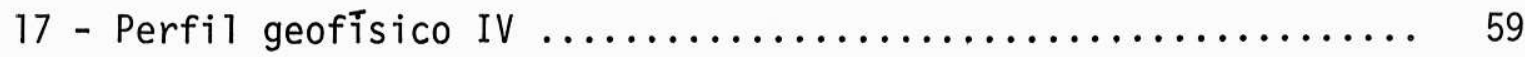

18 - Mapa de isoanomalia geoquímica e a posição do perfil III .... 66

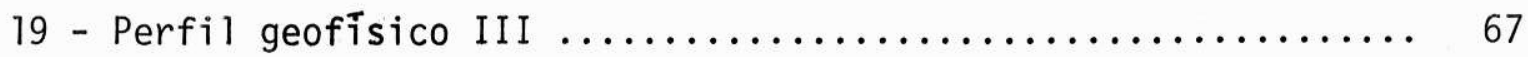

20 - Mapa de isoanomalia geoquímica e posição do perfil X ........ 68 


\section{A. 1 - RESUMO}

Um levantamento geofísico de prospecção de minērio de cobre sulfetado nos distritos cuprīferos da Mina de Camaquã, Rio Gran de do Sul e Mina Caraíba,Bahia, foi executado, aplicando-se o método eletro-magnētico indutivo de fonte mōvel.

A finalidade dos trabalhos foi a verificação da aplicabilidade do método e equipamentos na prospecção de minērios existen tes em filões ou disseminados numa matriz rochosa.

0 equipamento E.M. Sharpe, de construção canadense, não apresentou rendimento dada a sua baixa sensibilidade. 0 equipamentoE M Gun da ABEM, de construção sueca, mostrou-se muito eficāz na determi 
nação de anomalias em ambas as āreas estudadas.

Um total de mais de $60 \mathrm{~km}$ de perfis foram levanta dos, dos quais mais de $25 \mathrm{~km}$ no Rio Grande do Sul e o restante na Bahia.

Os trabalhos de campo foram divididos em duas fases. A primeira, uma fase preliminar, levada a cabo em regiões de geologia e mineralogia conhecidas. Comprovada a aplicação do equipamento e da metodo logia, era então desenvolvida uma campanha de prospecção geofísica.

Na Bahia, a fase preliminar foi executada não sō em locais de geologia e mineralização conhecidas, mas tambēm em āreas de ano malia geoquîmica. Constatou-se a presença de anomalias geofísicas em āreas de anomalias geoquîmicas. Um levantamento detalhado de uma ārea de algu mas dezenas de hectares foi aî executado a fim de se estabelecer a faixade anomalias geofísicas. Os dados obtidos nesta área foram tratados pela técnica do "trend surface analysis", comprovando-se a aplicabilidade dês te processo na delimitação de āreas geofĩsicamente anômalas.

Minērios com teores em sulfetos inferiores a 1,0\%, ou seja,aproximadamente $0,5 \%$ de $\mathrm{Cu}$, não provocam o aparecimento de anoma lias geofísicas.

Entre outros fatôres, falhas e concentrações de so- 
luções salinas prōximas à superfície provocam o aparecimento de anomalias.

Em laboratōrio foi desenvolvida uma fase experimental em modelos reduzidos. Este procedimento permitiu a elaboração de curvas que facilitaram a interpretação dos dados obtidos nos trabalhos de cam po. 
.4 .

\section{A.2 - INTRODUÇAO}

Mētodos eletro-magnēticos de prospecção geofĩsica, cujo desenvolvimento data de mais de meio século, têm sido usados em larga escala da prospecção mineral em diferentes partes do mundo.

Em paīses, principalmente da Europa Setentrional, o uso dêstes métodos de prospecção geofísica demonstrou grande poder de resolução e informação. Muitas jazidas, principalmente de sulfetos foram as sim encontradas.

Procuramos por meio dêste trabalho apresentar uma contribuição, divulgando os resultados obtidos na prospecção de minério de cobre, empregando-se pela primeira vez no Brasil, o método do eletro-magné 
tico indutivo de fonte mōvel.

0 principal objetivo dēste trabalho è o de geofísica aplicada, incluindo alguns dados teōricos, a fim de permitir uma melhor visão do método e da metodologia aplicados.

São dadas tambēm algumas informações geolōgicas das āreas estudadas, apenas para facilitar a compreensão dos problemas geofīsicos em discussão e justificar as diretrizes aplicadas no planejamento dos trabalhos de campo.

A fim de verificar a aplicabilidade do método na prospecção de minērio de cobre, os trabalhos de campo foram realizados nos distritos da Mina de Camaquã, onde o minērio ē do tipo filonar e da Mina Caraība, onde predomina minērio disseminado.

0 presente trabalho não poderia ter sido executadocaso não tivessemos tido o apôio de diversas entidades e numerosas pes soas.

Destaca-se o auxîlio proporcionado pelo GRUPO INDU TRIAL PIGNATARI, que não sō fornecendo os meios materiais, grande apôio proporcionou nos trabalhos de campo. Para tanto não podemos deixar de expressar aqui nos nossos sinceros agradecimentos ao Sr. FRANCISCO PIGNATARI, 
principalmente pela autorização de apresentar êstes dados obtidos.

Ao pessoal técnico da referida emprēsa, nas pessoas dos Engọs Neuclayr Martins Pereira, Fernando Lacourt, Dr. Sylvio de Queiroz Mattoso, aos geōlogos Wilson Fontanelli, Carlos Queirōz, Moacir Francisco Moço, Juarēz Soares de Souza, Maria Antonia Dias Pimentel Cesar, os meus sinceros agradecimentos pelo apôio concedido.

Não poderão, ser esquecidos os nomes do Prof. Dr. Rudolf Kollert, velho mestre e amigo que muito apōio técnico nos forneceu, bem como o Prof. Dr. Viktor Leinz pelo incentivo para a elaboração dêste trabalho.

Ao colega Dr. Gilberto Amaral, os meus sinceros agradecimentos pela cooperação na computação dos dados aplicando a técnica do "trend surface analysis".

Ao colega Prof. Dr. Reinholt Ellert, os meus agrade cimentos pelas sugestões e crîticas para a boa apresentação dêste trabaTho. 
.7.

\section{A.3 - EQUIPAMENTOS EMPREGADOS}

Como jā mencionado, para os trabalhos de campo foi aplicado o mētodo eletro-magnētico indutivo de fonte mōvel. Os equipamentos utilizados neste mētodo constam essencialmente de fonte e receptor de ondas eletro-magnéticas isoladas do solo e que são deslocadas na superfīcie do terreno, cobrindo a ārea a ser pesquisada.

Três foram os equipamentos utilizados, dois dos quais no campo e um apenas no laboratōrio.

0 primeiro equipamento, denominado E M Gun fabrica do pela ABEM da Suēcia- ē de fäcil transporte e operado por duas pessoas. Consiste de apenas duas unidades interligadas por um cabo, chamado de ca- 
bo de referēncia. A primeira unidade ē um transmissor como bobina trans missora. A segunda unidade ē um amplificador-compensador, com bobina de re cepção e fones.

0 transmissor consiste de um oscilador transistorizado, alimentado por baterias, acoplado à bobina transmissora que estā en rolada sôbre um nūcleo de ferrite. 0 oscilador opera em duas frequênciasciistintas, $880 \mathrm{c} / \mathrm{s}$ e $3520 \mathrm{c} / \mathrm{s}$, com uma potência de saî́da de $6 \mathrm{~W}$.

A fim de fornecer uma corrente de referência, quanto a amplitude e fase, existe uma segunda bobina, montada em paralelo com a bobina transmissora, que é ligada ao sistema compensador pelo cabo da re ferência acima mencionado. Êste cabo, além de conduzir a corrente de refe rēncia, serve tambēm para controlar o espaçamento entre os dois operado res.

0 sistema amplificador-compensador, que è carregado pelo observador, consta além das partes jā mencionadas, da bobina receptora, onde serā induzida a corrente provocada pelo campo eletro-magnético al terado. Por razões técnicas e eletrōnicas, o amplificador possui uma banda passante bastante estreita, onde somente as correntes de 880 e $3520 \mathrm{c} / \mathrm{s}$ devem ser amplificadas.

Em paralelo com o amplificador estā o sistema compensador que possibilitarā as medidas. ileste sistema são comparadas as 
.9 .

corrente vindas da bobina receptora e aquela induzida na bobina de referên cia, existente em paralelo com a bobina transmissora.

Considera-se executada a medida em um ponto, quando por meio de dois "diais" R e I se anula o som nos fones, som êste correspondente à corrente induzida na bobina receptora. A determinação desta "ạu sência de som" ē dada, não sō por via auditiva (fones), como também por via visual (micro-amperímetro).

Como parâmetro de medida, o equipamento efetua a de composição do vetor campo-eletro-magnético-resultante em suas componentes horizontal (chamada tambēm de I = imagināria ou "out of phase") e a compo nente vertical (chamada tambēm de $\mathrm{R}=$ real ou "in phase").

As medidas de I e $R$ são dadas em unidades de porcento, em relação ao campo eletro-magnético normal, para um determinado espa çamento entre as bobinas.

A sensibilidade do equipamento chega a ser de $0,2 \%$, para ambas as componentes das duas frequências.

0 segundo equipamento, denominado E M Sharpe, de construção canadense, tambēm consiste como o anterior, de uma unidade transmissora e outra receptor-amplificadora. 
A diferença fundamental entre êste aparêtho e o E M Gun é o parâmetro medido, que é o ângulo de inclinação do vetor campo-ele tro-magnētico resultante.

A medida é feita, colocando-se a bobina transmissora numa posição prē-determinada (horizontal, por exemplo). A bobina recep tora é movida de tal maneira a não se ouvir qualquer som nos fones. Neste instante mede-se o ângulo que esta bobina faz com o plano horizontal. Tal posição indica não haver qualquer linha de fôrça cortando a bobina receptora, ou seja, a bobina encontra-se no mesmo plano que contēm o vetor cam po eletro-magnético resultante.

Neste equipamento não existe qualquer elemento fĩsi co de ligação entre as unidades transmissora e receptora. A sua sensibili dade não é superior a 10 .

Em trabalhos de campo o método da medida do ângulode inclinação do vetor também pode ser utilizado empregando-se o equipa mento E M. Gun, quando o cabo de referência não é conectado.

0 terceiro equipamento, E M R K Lab, construĩdo pe10 Prof. Dr. Rudolf Kollert durante a sua estadia no Brasil, é utilizadosōmente em trabalhos de laboratōrio. Pormenores, esquema e funcionamento, serão dados em capítulo à parte. 
.11 .

\section{A. 4 - PROCEDIMENTOS DE CAMPO}

Como se trata de um trabalho pioneiro no Brasil, de prospecção de minērios sulfetados utilizando-se o mētodo eletro-magnētico alternado indutivo de fonte mōve1, não dispunha o autor de experiência quanto a metodologia desejāvel.

Para isto os trabalhos de campo nas regiões das $\mathrm{Mi-}$ nas de Camaquã e Caraíba obedeceram duas fases: a primeira preliminar e em seguida a de prospecção. 


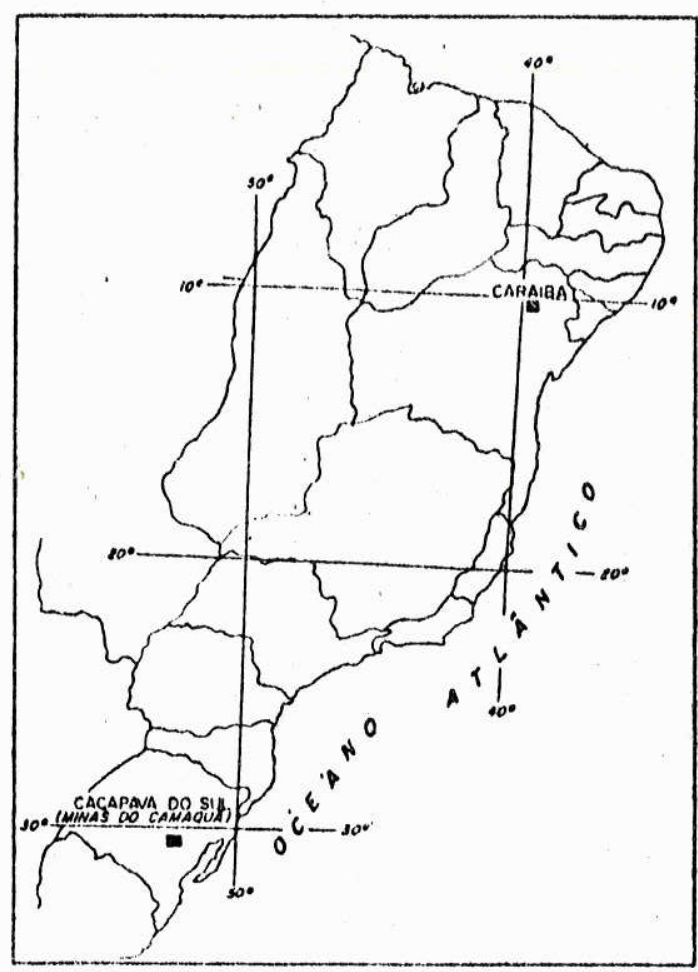

Figura 1 - Localização das áreas prospectadas

A fase preliminar foi por nōs primeiramente realiza da na região da Mina de Camaquã, em regiões de geologia e mineralização co nhecidas. Constituiu-se de levantamentos ao longo de perfis, transversais aos filöes, com pontos de medida espaçados de 20 metros. Para comparaçãode resultados, os dois equipamentos foram utilizados, observando-se que o equipamento E M Gun possui uma sensibilidade muito maior. Anomalias que atingem $60 \%$ (pico a pico) não foram acusadas pelo equipamento E M Sharpe.

A segunda fase, ou seja, de prospecção, era iniciada apōs comprovada a aplicabilidade do equipamento na prospecção de minērios sulfetados. 
.13.

0 procedimento de campo foi o mesmo em ambas as āreas prospectadas. Os pontos de medida eram dispostos ao longo de perfísperpendiculares à estrutura geolōgica.

$\mathrm{Na}$ ārea da Mina Caraība, alēm de serem medidos perfis sōbre corpos mineralizados, durante a fase preliminar, foram tambēm medidos perfis em āreas de anomalia geoquīmica. Neste distrito foi tambēm prospectada detalhadamente uma ārea de algumas dezenas de hectares, cuja finalidade foi de correlacionar as diferentes anomalias de um mesmo per fil, com as anomalias dos outros perfis, bem como testar a aplicação da tēcnica do "trend surface analysis" na delimitação de āreas geofīsicamente anômalas. 
.14 .

\section{A. 5 - DIFICULDADES ENCONTRADAS NO CAMPO}

Durante os trabalhos de campo foi notada uma série de fenōmenos que dificultaram ou mesmo chegaram a impedir a sua execução.

\section{A.5.1 - Descargas elētricas}

Como possuem grande energia, causam o aparecimento de um forte campo eletro-magnētico indutivo que se manifesta sob a formade um impulso que induz correntes na bobina receptora. Apesar do amplificador ser de banda estreita, o sinal captado é amplificado, provocando o aparecimento de um forte ruido nos fones e uma forte deflexão no micro-am perímetro. 
.15 .

Como as medidas são realizadas determinando-se o som mĩnimo, ou mesmo ausência de som e uma deflexão mīnima no micro-amperīmetro, tais fenômenos muito dificultaram os trabalhos de campo.

\section{A.5.2 - Eletricidade estātica}

Em regiões de clima sêco, como o é da Caraíba, a in tensidade da eletricidade estātica è grande e à semelhança das descargas $\underline{e}$ 1ētricas ocasiona dificuldades nas medidas. A intensidade dêste fenômenoaumentava considerāvelmente por volta das 10,30 horas da manhã. Não foram feitas observações para determinar o tērmino de tais perturbações. Em dias de umidade relativa mais alta, as perturbações eram mīnimas, permitindo trabalhos de campo o dia inteiro.

\section{A.5.3 - Fios de alta tensão}

Em distâncias inferiores a 200 metros, a influēncia da alta tensão é intensa. E causada provāvelmente pela variação de cargana linha, o que dā origem a impulsos eletro-magnēticos.

\section{A.5.4 - Tôrres de transmissão}

Tōrres de rādio e televisão, à semelhança da bobina 
transmissora, induzem correntes na bobina receptora gerando sinais que im pedem totalmente qualquer trabalho em suas proximidades.

\section{A.5.5 - Condutores artificiais}

A presença de qualquer condutor artificial na ārea que estā sendo prospectada deve ser cuidadosamente anotada. Tais condutores representados por tubulações de āgua, esgōto, gās, bem como trilhos de estrada de ferro, cêrcas de arame, etc., alteram os valores reais, pro vocando o aparecimento de uma falsa anomalia. 


\section{A.6 - FUNDAMENTOS TEORICOS}

\section{A.6.1 - Introdução}

A maior parte dos fundamentos teōricos descritos ē baseada em um memorando inédito fornecido pelo Prof. Dr. Rudolf Kollert.

Uma corrente elētrica alternada circulando pelo enrolamento de uma bobina (bobina emissora ou transmissora), cria ao seu re dor um campo eletro-magnético indutivo alternado.

Em qualquer bobina (bobina receptora), colocada nes te campo, aparecerā induzida uma corrente elétrica alternada, de sentidode circulação inverso ao da corrente primária. Esta corrente induzida terā a mesma frequência que a corrente primāria e estarā em fase com a mes- 
ma. A intensidade desta corrente induzida dependerā dos parâmetros da bobina receptora, da intensidade do campo primārio, bem como da distância que a mesma se encontra da bobina transmissora.

Assim como são induzidas correntes secundārias numa bobina, correntes tambēm são induzidas em corpos condutores, quando èstes se encontram em um campo eletro-magnético indutivo alternado.

A indução de correntes alternadas neste corpo condu tor cria ao seu redor, um campo eletro-magnético alternado.

Colocando-se uma bobina receptora em tal condição, a corrente induzida não mais serā causada exclusivamente pelo campo primā rio, mas sim pela superposição dos dois campos eletro-magnéticos. Êstes são o campo primário, criado pela corrente primária e o campo secundārio, criado pela corrente secundāria induzida no corpo, que somados darão o cam po resultante.

\section{A.6.2 - Campo Primārio}

0 campo primārio é criado pela passagem de corrente elétrica alternada pelas espiras da bobina transmissora.

Como as dimensões desta bobina são pequenas, quando 
.19 .

comparadas com a distāncia que separa normalmente as bobinas em trabalhos de prospecção (60 metros em mēdia), a forma das linhas de fôrça e a inten sidade do campo eletro-magnētico podem ser calculadas por meio de fórmulas para dipolos. Assim, para a construção das linhas de förça podemos usar a fōrmula:-

$$
r_{i}=r_{0} \operatorname{sen}^{2} \phi \quad \text { (figura 2) }
$$

e para o cālculo da intensidade do campo $F$, a expressão

$$
F=\frac{11}{d^{3}} \sqrt{1+\cos ^{2} \phi}
$$

onde

$\mathrm{d}=$ distāncia do ponto considerado ao centro da bobina

$M=$ momento magnético do dipolo $=I R^{2}$

$\mathrm{R}=$ raio da bobina

$I$ = intensidade da corrente que circula pela bobina 


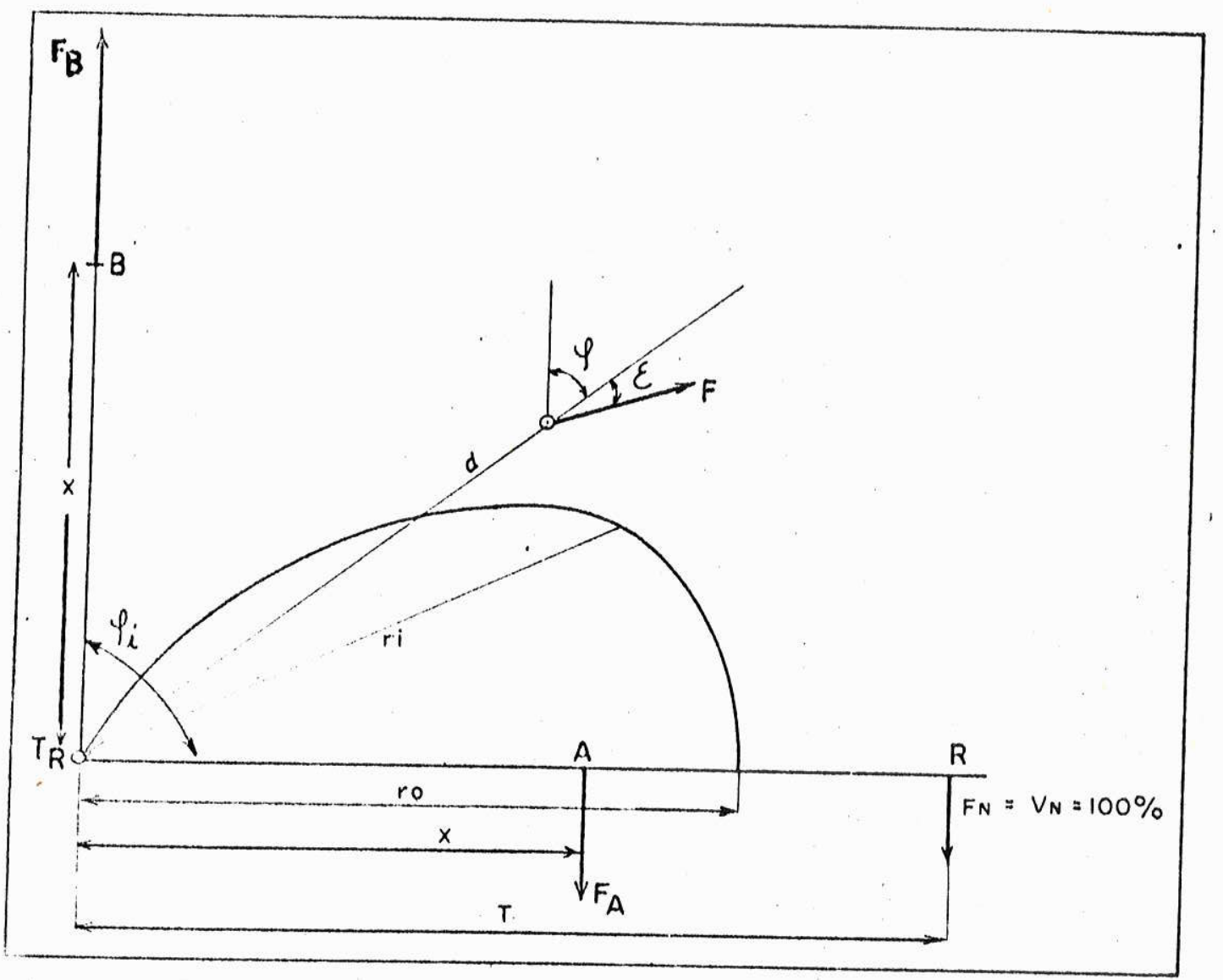

Figura 2 - Gräfico das linhas de fôrça

Como $\mathrm{R}$ è pequeno quando comparado com a distância que separa as bobinas, poderā ser desprezado, aparecendo assim:-

$$
F=\frac{I \pi}{d^{3}} \sqrt{1+3 \cos ^{2} \phi}
$$

Para se obter $F$ em tērmos absolutos, ē suficiente multiplicar por 0,1, ou seja:-

$$
F=0,1 \frac{I \pi}{d^{3}} \sqrt{1+3 \cos ^{2} \phi} \text { Gauss/Ampere }
$$


.21 .

Desta expressão (4) verifica-se que a fôrça $F_{A}$, no ponto $A$, situado à uma distância $\underline{X}$ do dipolo $(\phi=900)$, è dada pela expres são:-

$$
F_{A}=0,1 \frac{I \pi}{X^{3}}
$$

e a fôrça $F_{B}$, no ponto $B$, ao longo do eixo do dipolo $(\phi=0$ ) $)$, também a uma mesma distância, $\underline{X}$, ē dada pela expressão

$$
F_{B}=0,2 \frac{I \pi}{x^{3}}
$$

o que mostra que $F_{B}=2 F_{A}$. A direção é oposta $\bar{a}$ de $F_{A}$, pois as linhas de fôrça atravēs de $A$ e $B$ são de sentidos opostos.

0 campo eletro-magnético ( $F$ ) è tangente às linhas de fôrça no ponto de observação e formarā um ângulo $(\phi+\varepsilon)$ com a direção do eixo do dipolo. Os ângulo $\phi$ e $\varepsilon$ podem ser interrelacionados pela fórmu 1a:-

$$
\operatorname{tg} \varepsilon=\frac{1}{2} \operatorname{tg} \varepsilon
$$

Para uma bobina emissora vertical, a componente ver tical do campo em qualquer ponto (N) serā dado pela fórmula geral:-

$$
V_{N}=F \cos (\phi+\varepsilon)
$$

Para a condição onde $\phi+\varepsilon=90$ ! teremos 


$$
\begin{array}{r}
\operatorname{tg} \phi+\varepsilon=\frac{\operatorname{tg} \phi+\operatorname{tg} \varepsilon}{1-\operatorname{tg} \phi \cdot \operatorname{tg} \varepsilon}=\frac{\operatorname{tg} \phi+1 / 2 \operatorname{tg} \phi}{1-\operatorname{tg} \phi \cdot 1 / 2 \operatorname{tg} \phi}=\infty \\
\text { Para } 1-1 / \operatorname{tg}^{2} \phi=0 \quad \phi=540 \text { 44' }
\end{array}
$$

0 campo eletro-magnētico è horizontal (māximo de $1 \underline{i}$ nhas de förça) ao longo da linha que forma um ângulo $\phi=54944^{\prime}$ com a horizontal.

A construção dēste grāfico ē feita da seguinte ma neira: um ponto $\underline{\mathrm{R}}$ (receptor) é escolhido na abcissa a uma distāncia $\underline{T}$ da bobina $\operatorname{Tr}$ (transmissora) onde o campo normal $F_{N} \bar{e}$ tomado como sendo igual

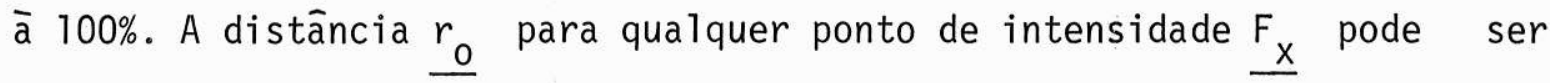
calculado fäcilmente pela fórmula (5) onde:

$$
\begin{aligned}
& F_{N}: F_{X}=1 / T^{3}: 1 / r_{0} \\
& r_{0}=T \sqrt{\frac{F_{N}}{F_{x}}}=T \sqrt{\frac{100}{F_{x}}}
\end{aligned}
$$

$$
\text { Assim, por exemp1o, para campos de intensidade }
$$

$\mathrm{F}_{\mathrm{X}}=800 \%, 400 \%, 200 \%, 50 \%$, teremos respectivamente, $r_{0}=0,5 \mathrm{~T} ; 0,631 \mathrm{~T}$; 0,794T e 1,26T (vide figura 3).

As linhas de förça, passando atravēs dêstes pontos, são construĩdas aplicando-se a fórmula (1) que nos darā as distāncias $\underline{r}$ para os diferentes ângulos. 
As linhas de equi-intensidade são construĩdas utilị zando-se a fórmula (2).

Para o ponto $\underline{R}$, a equação serā:

$$
F_{R}=\frac{M}{T^{3}} \sqrt{1+3 \cos ^{2} 900}=\frac{M}{T^{3}}
$$

Nos demais pontos da curva de iso-intensidade que passa por $\underline{R}$, a equação terā a forma geral:

$$
F_{d}=\frac{M}{d^{3}} \sqrt{1+3 \cos ^{2} \phi}
$$

e como $F_{d}=F_{R}$, podemos escrever:

$$
\frac{M}{T^{3}}=\frac{M}{d^{3}} \sqrt{1+3 \cos ^{2} \phi}
$$

Qualquer ponto com intensidade de campo $F_{x}$, terā co mo expressão:

$$
F_{x}=\frac{M}{r_{0}^{3}} \sqrt{1+3 \cos ^{2} \phi}
$$

ou então, considerando-se a fórmula (1):

$$
d_{x}^{3}=\frac{100}{F_{x}} \cdot T^{3} \sqrt{1+\cos ^{2} \phi}
$$


Como ilustração sôbre as condições do campo eletrohagnëtico em tōrno de um dipolo vertical, a figura 3 mostra os vetôres da intensidade total e da componente vertical nos pontos onde o ângulo $\phi=09,309,509,54944^{\prime}, 609,809$, para uma mesma distāncia $d_{x}=T=1$ do dipolo.

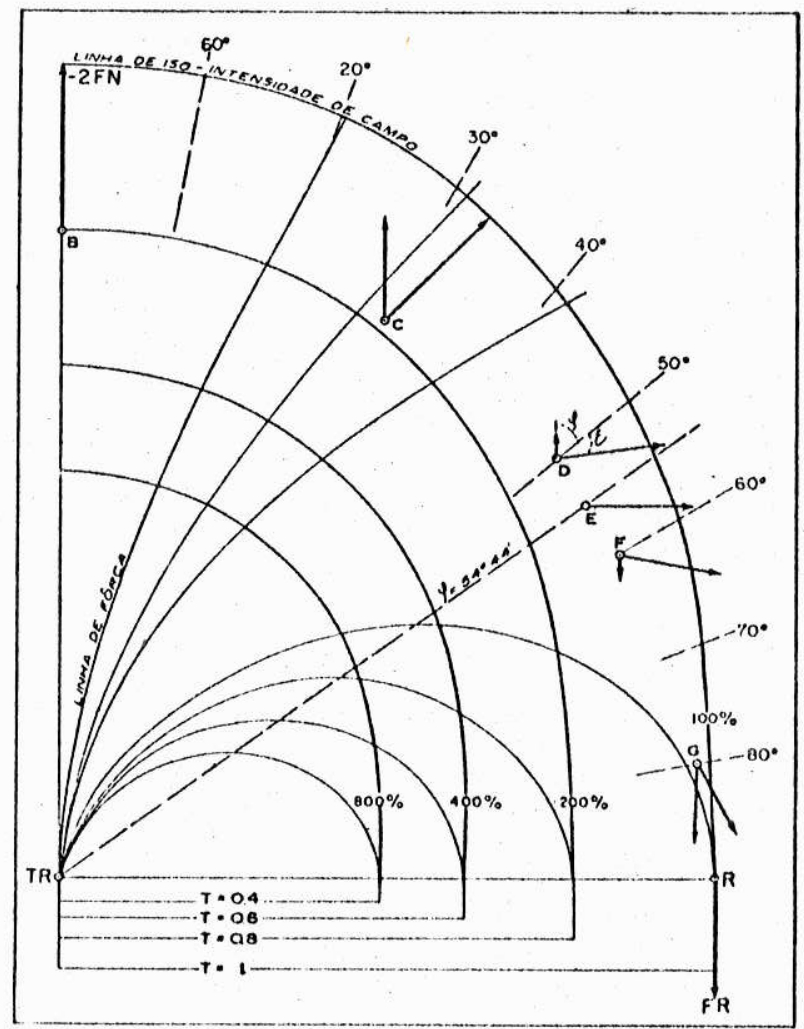

Figura 3 - Campo eletro-magnético de um dipolo.

\section{A.6.3 - Correção Topogräfica}

E muito raro, em trabalhos de campo, que ambas as 
bobinas se encontrem no mesmo plano. Havendo uma diferença de cota, è necessārio efetuar-se uma correção na componente real R, ou sejá, na componente vertical.

A figura 3 anexa, exemplifica o fenômeno, ou seja , a variação da intensidade da componente com a topografia.

Os pontos E, F, G e R, locados à uma mesma distān cia de $\mathrm{Tr}$, mostram uma diminuição da componente com um aumento da diferen ça de elevação entre as duas bobinas.

Normalmente, no campo não são executados trabalhosem encostas com declives superiores à 250, não só pela grande correção a ser efetuada, como também pelas dificuldades de deslocamento dos operadores.

0 sinal da correção è sempre positivo, isto é, o va lor da correção deverā ser sempre adicionado ao valor $\mathrm{R}$ medido, indepen dentemente da cota absoluta da bobina receptora. 
.26 .

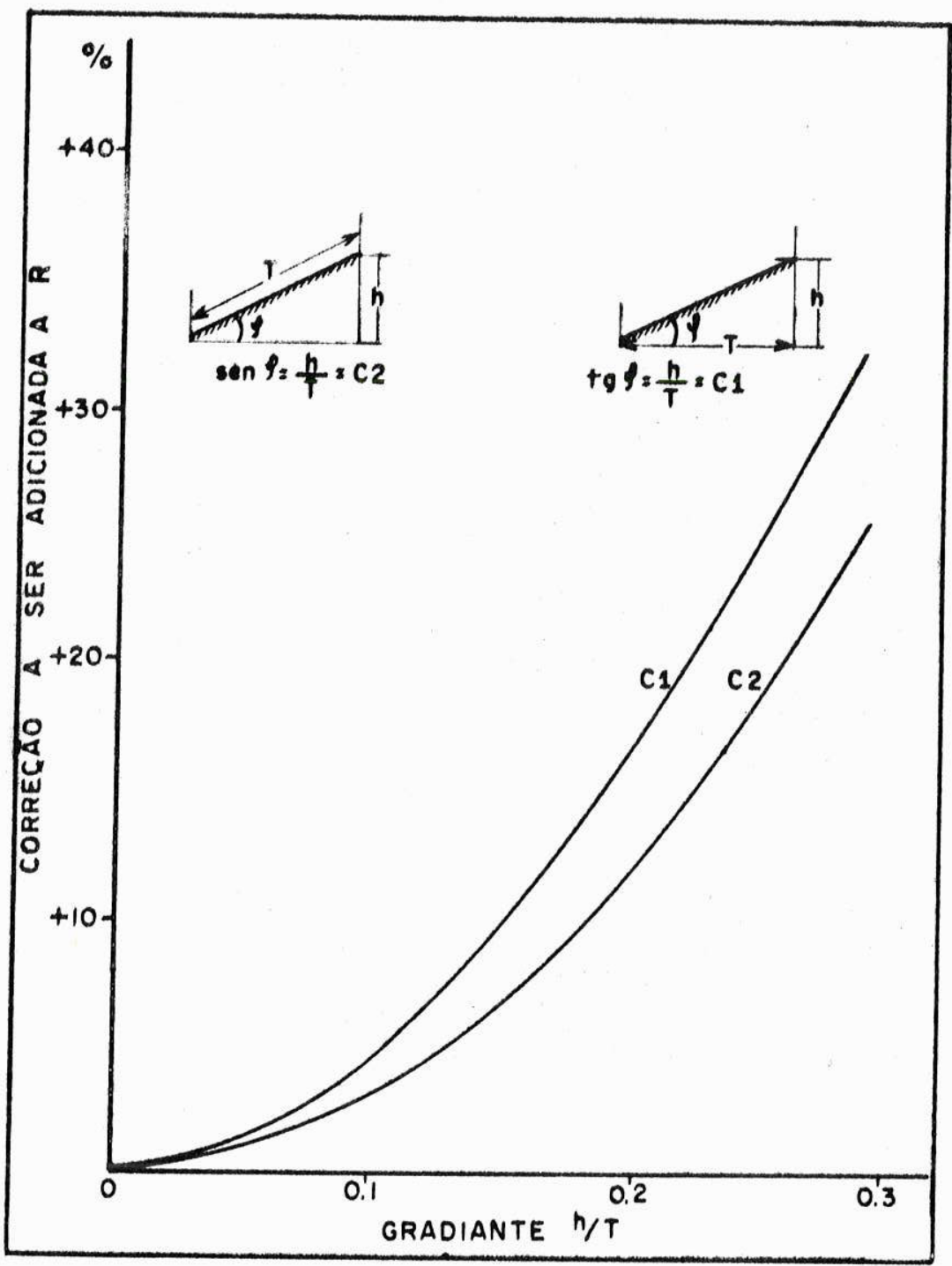

Figura 4 - Gräfico para a correção topogräfica.

0 valor da correção é dado por:

$K=F_{N}-V_{i}$ 
onde $\mathrm{F}_{\mathrm{N}}=$ campo normal $(=100 \%$ ) no ponto $\underline{\mathrm{R}}$ situado à uma distância $\underline{T}$ do dipolo e $V_{i}=$ componente vertical teörica do campo primärio no ponto de observação.

$V_{i}$ pode ser calculado por meio das fórmulas (7) e (8), depois de determinado o valor $\phi$ pela relação:

$\cos \phi=h / T$, onde $\underline{T} \bar{e} o$ espaçamento entre as bobi nas e $h=$ diferença de cota.

Quando a topografia ē suave, o êrro devido a topo grafia pode ser negligenciado, uma vez que o mesmo cai dentro da sensibilidade do equipamento.

Normalmente em trabalhos de campo, trabalha-se dentro de uma margem de êrro de 1\%. Observando-se a tabela para 1\% de correção, a relação h/T é igual a 0,06, ou seja, para um espaçamento I de 60 me tros, a diferença de cota $\underline{h} \bar{e}$ igual a 3,60 metros.

Quando se requer uma interpretação acurada e as ano malias encontradas são pequenas, faz-se necessāria a correção. 


\section{A.6.4 - Componente Resultante}

Como hä uma grande diversificação na medida de parâa metros eletro-magnēticos e por conseguinte, uma grande variação instrumen tal e operacional, hă diferentes maneiras para se representar uma anomalia

As anomalias aqui descritas e apresentadas, são aquelas encontradas quando se aplica um equipamento eletro-magnético indutivo de fonte móver, tal como o E M Gun, da ABEM.

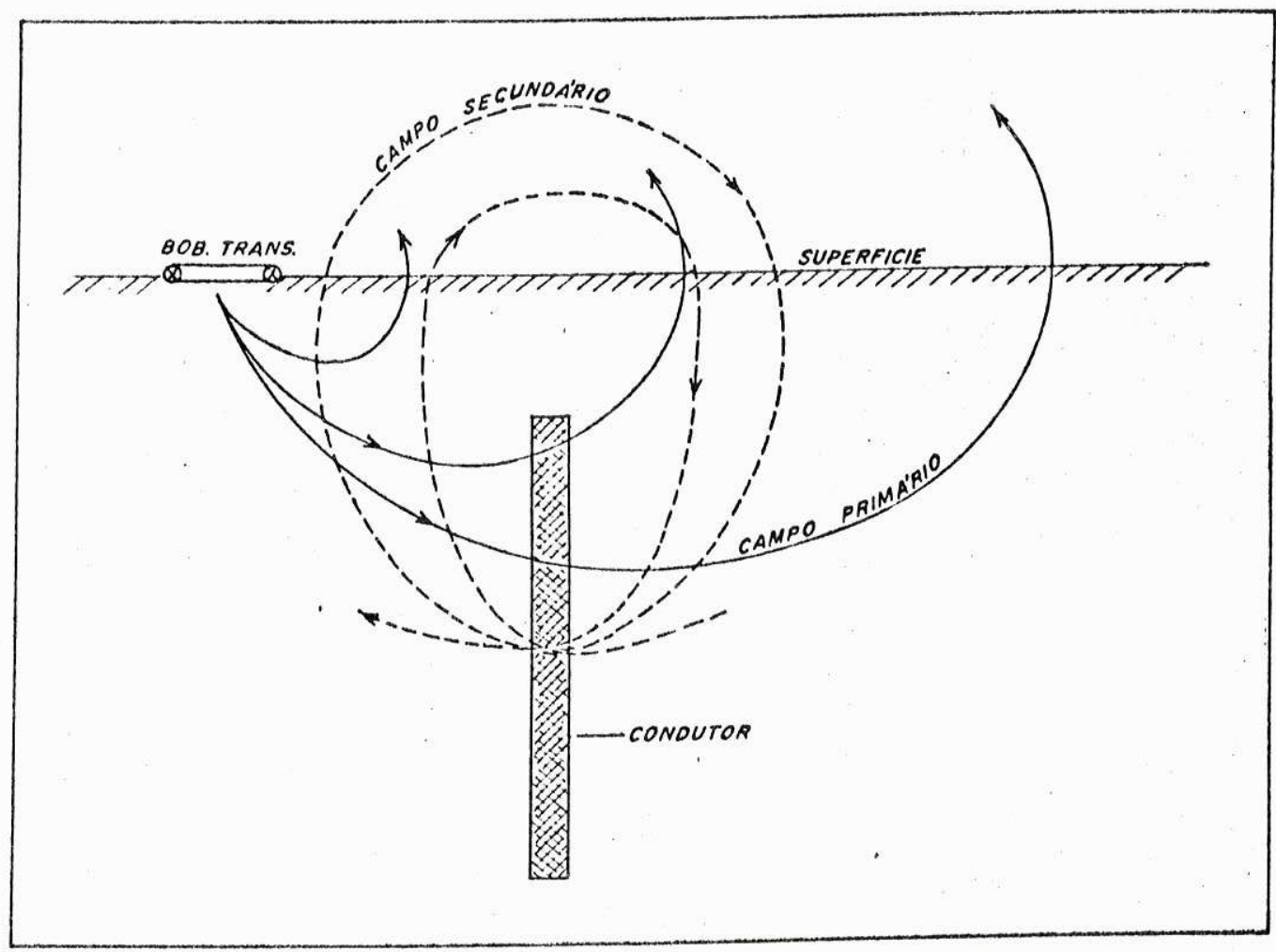

Figura 5 - Campos primário e secundärio. 
A figura acima permite visualizar claramente o fenō meno da indução eletro-magnética. Ela mostra o caso de um corpo condutorvertical, de forma tabular, situado em um campo eletro-magnético alternado.

Suponhamos que em um certo instante a corrente este ja fluindo na bobina transmissora, no sentido anti-horārio (quando a bobi na ē vista de baixo). As linhas de fôrça, representando o campo primārio, terão sentido de baixo para cima, ao longo de todos os pontos da superfīcie do terreno (princīpio da mão direita). As correntes secundārias induzidas no corpo condutor terão sentido oposto ao da corrente primāria.

Por razões geomētricas, a componente vertical do campo secundārio tem o mesmo sentido que o campo primārio em pontos da su perficie situados entre a bobina transmissora e o corpo condutor, e senti do oposto em pontos situados à direita do condutor. Consequentemente, a componente vertical observada serā maior que o campo primārio se ambas as bobinas estiverem do mesmo lado do corpo condutor, enquanto que serā menor que o campo primärio se o condutor se encontrar entre as bobinas.

0 gräfico da figura 6 ē obtido colocando-se em orde nadas o campo ou componente de campo medida e em abcissa o ponto médio en tre as bobinas transmissora e receptora, ou seja, a estação de observa ção. 
.30 .

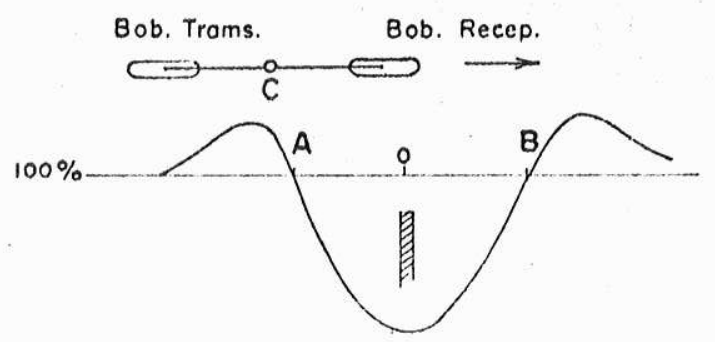

Figura 6 - Intensidade da componente vertical.

Um amortecimento māximo ē obtido na estação $\underline{0}$ (verticalmente sôbre o corpo condutor) onde as bobinas estão situadas nos pon tos $A$ e $B$ respectivamente (simétricos ao corpo condutor).

Os pontos A e B são portanto de um certo interêsse--

pois:

- quando se mede na estação $\underline{A}$, a bobina receptora estā localizada no ponto $\underline{\underline{0}}$. Neste ponto o campo secundārio ē horizontal (vide figura 5) e por tanto a componente vertical corresponde exatamente ao campo primário.

- quando se mede na estação $\underline{B}$, a bobina transmissora se encontra no ponto 0. Neste ponto nenhuma corrente é induzida no corpo condutor pelo fato do campo primärio ser vertical e novamente só o campo primärio é registrado $(\overline{A B}=T$, onde $T=$ espaçamento entre as bobinas $)$. 
0 princĩpio usado para a construção da curva resultante ē välido tambēm para outras orientações mútuas das bobinas, por exemplo, horizontais, como tambëm para condutores com outras formas e/ou $\underline{0}$ rientações relativas. As curvas porém, serão diferentes daquela acima representada.

As condições de amplitude e fase de um campo eletro -magnētico, onde estā presente, alēm da corrente primāria, a corrente secundāria e os seus respectivos campos, bem como o campo resultante, podem ser representados pelo gräfico de um movimento harmōnico descrito por uma corrente alternada.
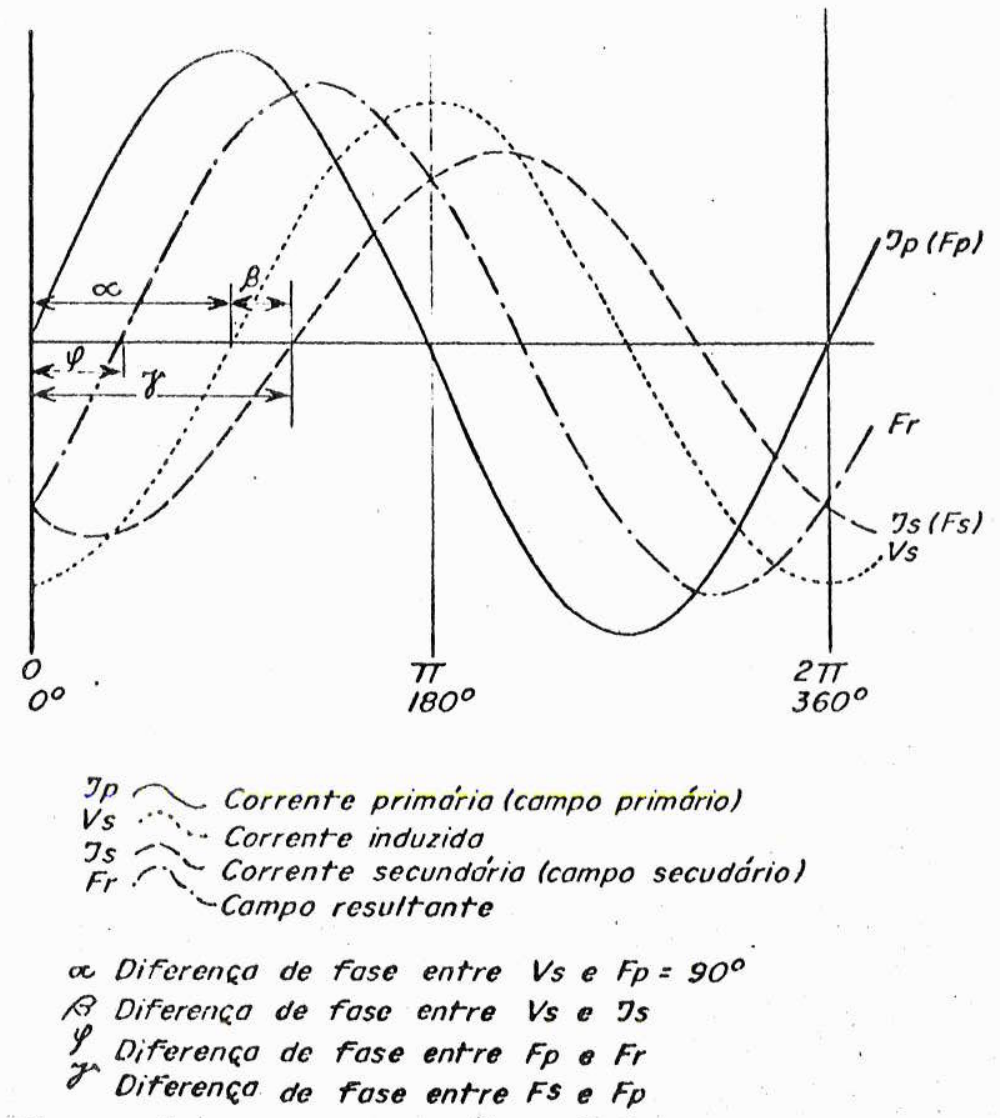

Figura 7 - Representação gräfica das correntes. 
A figura 8, mostra a correlação geométrica entre as componentes I e R, a componente resultante o ängulo da diferença de fase.

$$
\begin{aligned}
& (\mathrm{RC})=F_{r} \cos \phi \\
& (I C)=F_{r} \operatorname{sen} \phi
\end{aligned}
$$

Esta figura ē uma representação vetorial do movimen to harmönico representado na figura 7 .

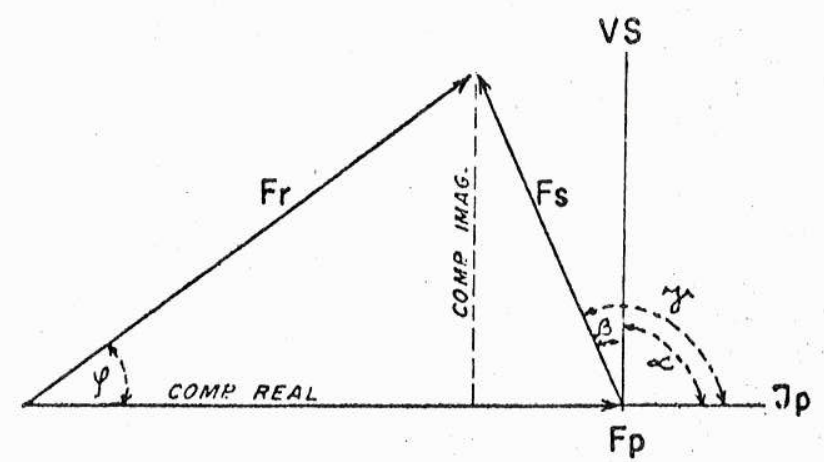

Figura 8 - Representação vetorial do movimento harmônico.

$F_{r}=$ campo resultante

$F_{p}=$ campo primärio

$F_{S}=$ campo secundärio 
.33 .

\section{A.7 - EXPERIÊNCIAS EM MODELOS REDUZIDOS}

\section{A.7.1 - Introdução}

Em alguns métodos geofísicos de prospecção pode-sechegar à uma interpretação quantitativa das anomalias encontradas, por meio de fōrmulas matemāticas ou então por comparação com curvas teōricascalculadas matemāticamente, determinando-se assim os parâmetros do corpocausador da anomalia.

Para o mētodo eletro-magnētico indutivo, grāficos pa ra fins de interpretação são construĩdos fācilmente de modo experimental, por meio de medidas em modelos reduzidos, onde se variam as caracterīsticas geométricas e elétricas do sistema. 
.34

0 estudo do comportamento do campo eletro-magnético indutivo alternado em modelos reduzidos ē muito importante, prático e con clusivo, pois ē possīvel, em laboratōrio, simularem-se condições encontra das em trabalhos normais de prospecção.

Tais modelos devem porēm, obedecer a chamada "lei da escala", que estabelece que: o campo eletro-magnético indutivo em modelos reduzidos terá a mesma distribuição que aquêle de trabalhos normais de cam po, se a intensidade da corrente e tôdas as dimensões, incluindo o parâme tro $\underline{L}$, forem mudados na mesma proporção.

$$
L=\frac{\rho}{f d} \quad \begin{array}{ll}
\rho & =\text { resistividade } \\
f & =\text { frequência } \\
d & =\text { espessura }
\end{array}
$$

Quanto $\bar{a} \underline{L}$ a relação (15) estabelece que:

- se ambos $\underline{L}$ e $\underline{d}$ forem multiplicados (ou divididos) por um fator $\underline{K}$, o parâmetro $\rho$ (resistividade) serā dividido (ou multiplicado) por $\mathrm{K}^{2}$.

\section{A.7.2 - Equipamento Empregado}

Fonte de ondas

A fonte de ondas utilizada constou de um osciladorà vāivulas, com 3 frequências de oscilação, a saber $130 \mathrm{c} / \mathrm{s}, 260 \mathrm{c} / \mathrm{s}$ e $560 \mathrm{c} / \mathrm{s}$. 
A razão da utilização de um oscilador com diferen tes frequências era observar a amplitude (pico a pico) da anomalia, empre gando-se diferentes frequências, em um mesmo modêlo.

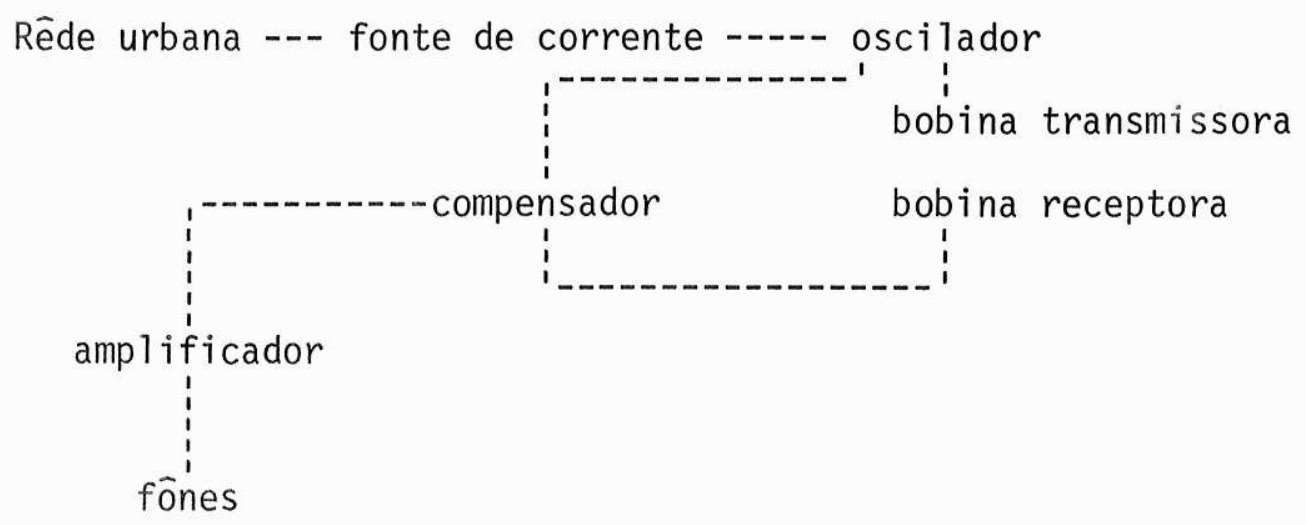

Esquema I - Diagrama de circuíto.

\section{Compensador}

E a unidade de medida prōpriamente dita do equipa mento. 0 compensador tem por finalidade determinar a intensidade da compo nente resultante e a diferença de fase existente entre as correntes primá ria e secundāria.

Estas medidas, tais como no equipamento utilizado no campo, são feitas decompondo-se o vetor campo eletro-magnético resultante em suas componentes I e R.

A corrente de referência é obtida por meio de bobi- 
.36 .

nas acopladas diretamente em paralelo à instalação que alimenta a bobinaemi ssora.

\section{Bobinas}

Tanto a trnamissora como a receptora são de peque nas dimensões $(\emptyset$ de $2 \mathrm{~cm}$ ), fixadas numa placa de acrīlico, que è deslocada sôbre o modêlo durante as medidas.

0 espaçamento entre as bobinas podia ser alterado, variando-se de 6 a $12 \mathrm{~cm}$, o que corresponderia a 60 e 120 metros, respectivamente, em trabalhos de campo.

Amplificador

A unidade amplificadora usada era um amplificador de eletrola para alta fidelidade.

Como amplificadores déste tipo possuem uma banda pas sante muito ampla, frequentemente eram notadas dificuldades nas determina ções de R e I.

Como alēm da corrente do oscilador, eram tambēm amplificadas correntes provocadas pela indução devida a rêde urbana, ou seja, 60 c/s, a medida na realidade, se resumia não em uma ausência de som, mas sim de um ponto de som mīnimo. 0 fenōmeno era tambēm parcialmente pro 
vocado pela polarização elíptica, devido a alta condutividade dos modelos.

\section{Fones}

Como as medidas eram feitas exclusivamente por via auditiva, os fones tinham por finalidade transmitir o som e isolar os ruĩ dos externos, permitindo uma acurada determinação das medidas.

\section{A.7.3 - Resultados 0btidos}

\section{A.7.3.1 - Dimensionamento dos modelos}

Como vimos anteriormente, o método eletro-magnētico indutivo ē repetitivo, quando são guardadas algumas relações.

0 exemplo a seguir tem por finalidade demonstrar o dimensionamento de um modêlo.

- suponhamos que haja o interêsse de se estudar a anomalia que seria obti da em medidas no campo, realizadas com um equipamento E M Gun, com espa çamento de 40 metros entre as bobinas, atravēs de um corpo condutor de 0,80 metros de espessura e uma resistividade de 46 ohm.m. A experiēncia com modelos reduzidos seria realizada com a mesma frequência que no cam po, com bobinas espaçadas de $10 \mathrm{~cm}(100 \mathrm{~mm})$.

Como a relação de escala ē 1/400, a espessura e a re sistividade do modêlo serão respectivamente: 


$$
\begin{aligned}
& d_{e}=800 / 400=2 \mathrm{~mm} \\
& \rho_{e}=0,46 / 400^{2}=2,88 \cdot 10^{-6} \mathrm{ohm} . \mathrm{cm}
\end{aligned}
$$

ou seja, um modêlo representado por uma placa de alumīnio

$$
\left(\rho=2,9 \cdot 10^{-6} \text { Ohm.cm) com espessura de } 2 \mathrm{~mm}\right. \text {. }
$$

0 inverso do exemplo acima è frequentemente realiza do para fins de se procurar interpretar as anomalias encontradas duranteas medidas de campo.

Como decorrēncia da fōrmula (15), observações con firmam que diferentes condutores tabulares tendo o mesmo valor $\underline{L}$, causam anomalias idênticas, se a frequência e a escala não forem mudadas. Portan to, ē a relação entre a resistividade e espessura do corpo que determina a influência de um condutor no comportamento do campo eletro-magnético e não os seus valores individuais.

E possīvel em laboratōrio aumentar a espessura $\underline{\mathrm{d}} \mathrm{e}$ diminuir a resistividade $\underline{\rho}$, mantendo-se sempre o mesmo parâmetro $\underline{L}$. Verifica-se porēm que tal relação ē vālida sōmente para placas delgadas, ou seja,

d $\quad 30 \frac{d}{f}$ metros, quando $\underline{\rho} \bar{e}$ expresso em $0 \mathrm{hm} . \mathrm{cm}$ 


\section{A.7.3.2 - Exemplos de curvas obtidas}

1) - Corpo vertical representado por uma placa de aluminio, com espessura de $0,5 \mathrm{~mm}$. 0 espaçamento entre as bobinas $T=100 \mathrm{~mm}$. A frequência utilizada era constante. A variāvel nestas medidas foi a pro fundidade, ou seja, variou-se a relação $\mathrm{T} / \mathrm{a}$, onde $\mathrm{a}=$ profundidade.

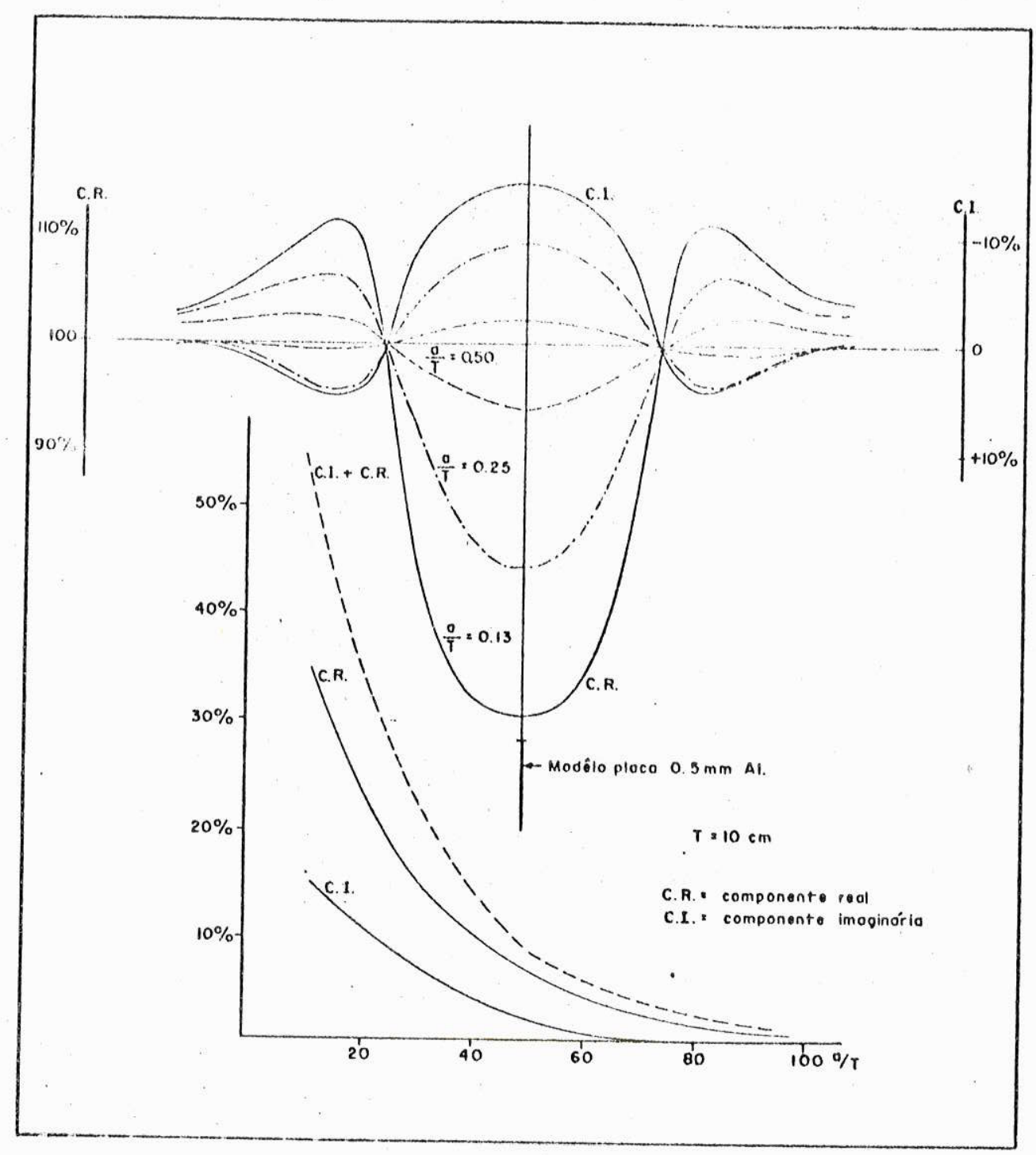

Figura 9 - Modêlo vertical em profundidades variadas. 
A figura acima mostra a variação da amplitude da anomalia com a variação da relação $T / a$.

Verifica-se que a amplitude da anomalia decresce for temente com um pequeno aumento na relação $T / a$, para depois se tornar as sintōtica ao eixo das abcissas.

2) - Corpo vertical (placa de alumīnio), profundidade constante, espaçamento entre as bobinas constante, sendo variada a frequēn cia da corrente primāria.

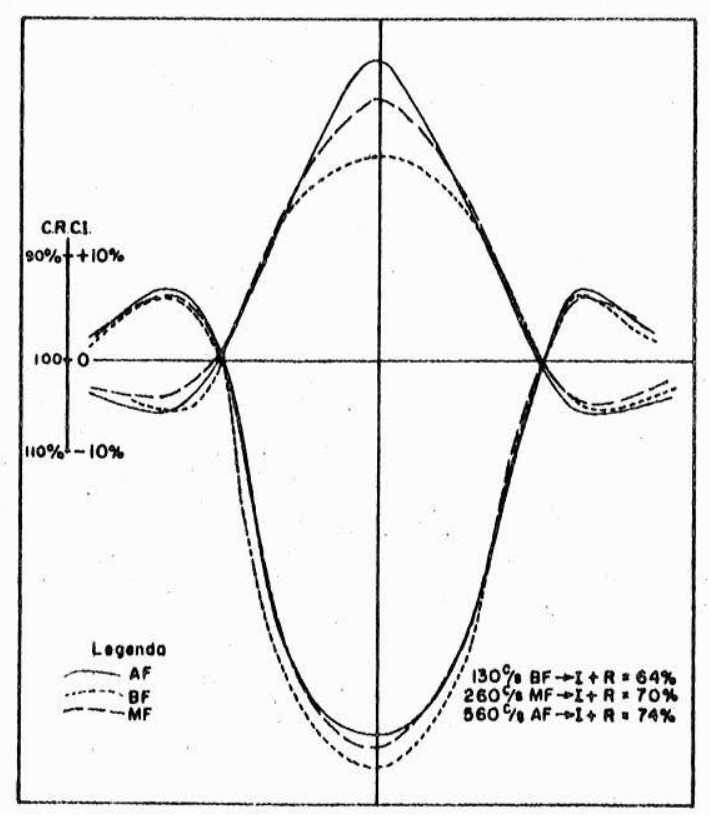

Figura 10 - Corpo vertical, frequências variadas

A figura acima mostra uma variação na amplitude da .$/$ 
anomalia em função da frequência empregada.

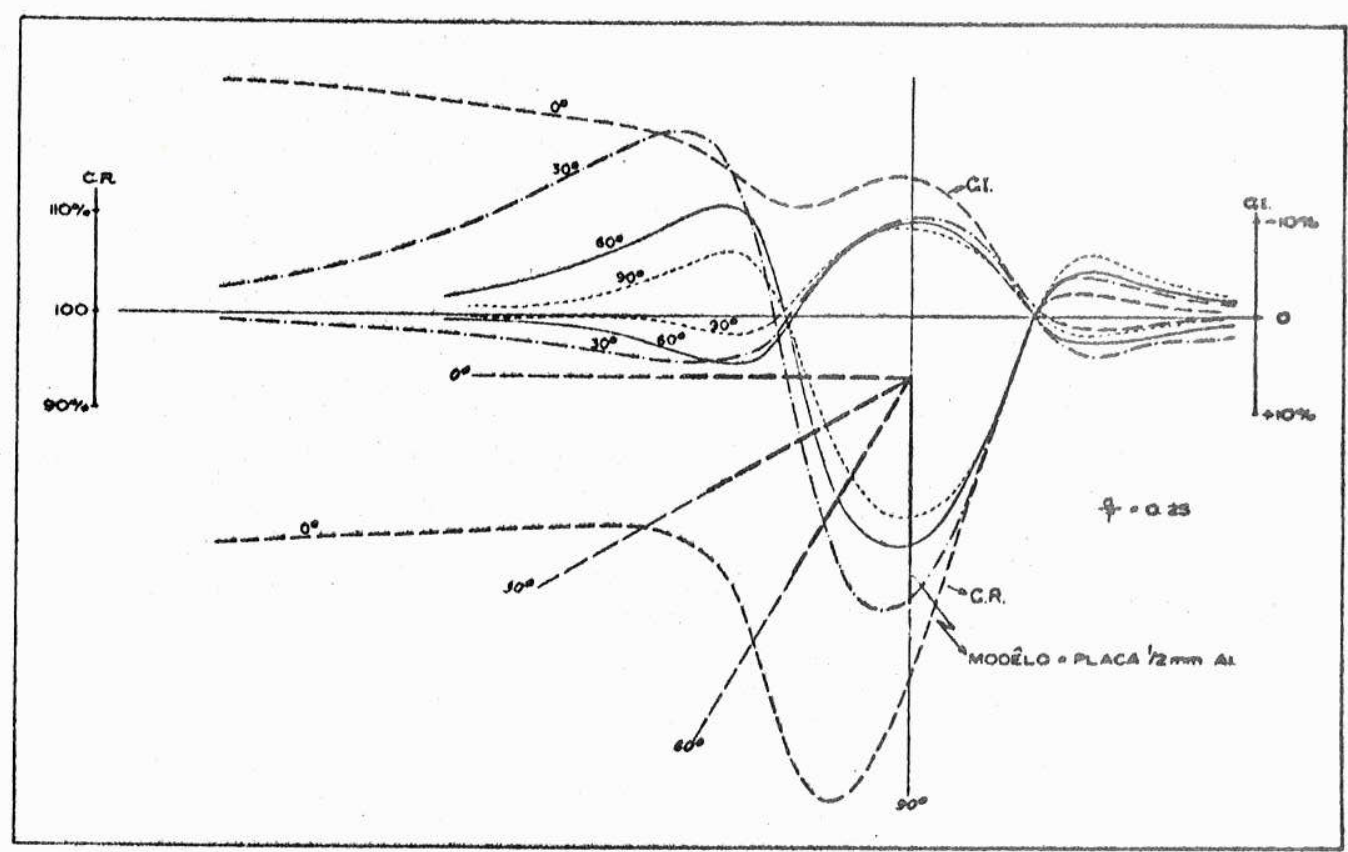

Figura 11 - Modêlo com diferentes ângulos de inclinação.

Com base nas figuras apresentadas ē possivel uma se् rie de conclusões quanto a correlação da forma e amplitude de uma anoma Ita encontrada no campo e o possĩvel corpo causador da anomalia, bem como a sua postção geoiögica.

Verifica-se por meio das curvas que:-

a) - a anomalta ë mäxima quando as bobinas se encontram simētricas ao cor po, ou seja, quando o corpo se encontra no centro do sistema de bobi has. 
b) - os valores de $R=100 \%$ e $I=0 \%$ são obtidos quando qualquer uma das bobinas se encontra sôbre o corpo.

c) - verifica-se um decréscimo na amplitude da anomalia com um aumento da profundidade do corpo condutor

- para $a / T=0,13$ distância entre os picos $=50 \%$

- para $a / T=0,25 \quad " \quad " \quad "=30 \%$

- para $a / T=0,50 \quad " \quad " \quad "=8 \%$

d) - quanto ao mergulho, a coletânea de curvas da figura 11 mostra clara mente uma variação no aspecto da curva em função do mergulho do cor po causador da anomalia. Esta experiência mostra que por meio dêste método de levantamento geofísico é possīvel a locação geogrāfica do corpo causador da anomalia e o seu eventual rumo do mergulho. 0 valor do ângulo poderā ser inferido, mas não determinado exatamente.

e) - atē agora foram feitas apenas referências à anomalias provocadas por corpos tabulares, cuja largura é inferior ao espaçamento que separa as bobinas. Se o corpo possui uma largura superior ao espaçamento en tre as bobinas, êle tambēm provocarā o aparecimento de uma anomalia como mostra na figura 11, a curva medida sôbre o modêto em sua posi ção horizontal.

f) - as curvas medidas com frequência variada mostram que a amplitude da anomalia depende da frequência empregada. A amplitude é maior quanto maior a frequência, pois com o aumento da frequência aumenta o fator indutivo. 


\section{B. 1 - CAMAQUA}

\section{B.1.1 - Geologia}

\section{B.1.1.1 - Geologia local}

As Minas de Camaquã, estão localizadas à sul do Município de Caçapava do Sul, Estado do Rio Grande do Sul, distando da sede do referido Município, cêrca de $66 \mathrm{~km}$.

Geolōgicamente a ārea é constituida por uma sequência de camadas sedimentares, que possui cêrca de 4.000 metros de espessura (Robertson, 1966).

Os sedimentos são de ambiente continental, com ca racteristicas muito semelhantes o que dificulta o estabelecimento de uma estratigrafia segura.

A região foi submetida à ação de magmatismo andesî̉ tico, bem como à um intenso tectonismo, que provocou falhamentos e dobra mentos.

Estruturalmente, a região das Minas é constituīda- 
por um anticlinal com eixo de direção N-S. Como a crista dêste anticlinal é menos resistente, a ação da erosão expōs formações mais antigas co mo os Membros Vargas e Mangueirão. A topografia é relativamente acidenta da com diferenças de nīvel de atē 200 metros.

\section{B.1.1.2 - Estratigrafia e 1itologia}

A coluna estratigrāfica da região, segundo os trabalhos do DNPM, publicados em 1966, ē a seguinte:

Sedimentos recentes

Grupo Camaquã $\left\{\begin{array}{l}\text { Membro Rodeio Velho } \\ \text { Formação Santa Bārbara }\end{array}\right.$

discordância erosiva

Grupo Bom Jardim - Formação Arroio dos Nobres $\left\{\begin{array}{l}\text { Membro Vargas } \\ \text { Membro Mangueirão }\end{array}\right.$

Os sedimentos recentes são representados por casca Thos e areias provenientes da decomposição dos sedimentos conglomerāti cos. 


\section{GRUPO CAMAQUA}

0 Membro Rodeio Velho é constituido de sedimentos a renosos intercalados com lavas andesīticas.

A Formação Santa Bārbara è exclusivamente sedimen tar, onde estão presentes, alēm de arenitos, conglomerados ricos em sei xos de riōlito.

\section{GRUPO BOM JARDIM}

0 Membro Vargas, à semelhança da Formação Santa Bār bara, ē tambēm formado de arenitos e conglomerados. A caracterīstica marcante $\bar{e}$ a presença de seixos de rochas igneas e metamōrficas formando 0 conglomerado.

0 Membro Mangueirão apresenta litologia mais variada e granulação mais fina. E constituido de siltitos, argilitos, arcósios micāceos e grauvacas.

\section{B.1.1.3 - Mineralização}

Na região da Mina de Camaquã verificou-se que hā um contrōle estrutural muito bem definido, bem como um possível contrôle litolögico. 
As estruturas controladoras na formação dos veiosforam falhas e fraturas. As falhas regionais, de direção NE, no geral,es tão isentas de mineralização. Esta estā associada à falhas subordinadas, de pequeno rejeito, com direção preferencial NW e mergulhos sub-verticais.

Os veios mineralizados são de preenchimento, apresentando espessuras variadas, com mineralização disseminada nas encaixan tes.

Pesquisas efetuadas pela Companhia Brasileira do Cobre sugerem que o Membro Vargas atuou como principal contrôle litológi co. Não obstante, pode ocorrer tambēm mineralização no Membro Mangueirão.

Os filões em exploração são: Filão S.Luiz, Barnabé, S.Julio, Uruguai, todos com direções que variam de $\mathrm{N}-20-\mathrm{W} \overline{\mathrm{a}} \mathrm{N}-70-\mathrm{W}$. Os filões Oscarino, Feliciano, Piritas não estão sendo minerados. A espessu ra é variāvel, podendo atingir alguns metros. Atualmente a maior produ ção provēm dos filões S.Luiz e Uruguai, onde a zona mineralizada compreendendo minério de preenchimento e disseminado pode atingir atē 10 me tros de espessura.

0s principais minerais de minério, descritos por Leinz e Almeida (1944), são:

a) - carbonatos: malaquita e azurita 
b) - silicato: crisocola

c) - óxido: cuprita

d) - sulfetos: calcosina, covelina, calcopirita, bornita e pirita.

Os principais minerais de ganga são: quartzo, 1 imo nita, hematita e barita.

Junto à superfície è comum uma zona completamentelixiviada, com poucos remanescentes de minerais de minério. Na zona de $\underline{0}$ xidação encontram-se quantidades apreciāveis de calcosina, que ē o sulfe to secundārio mais importante. Raramente tem sido encontrado cobre nativo. Nesta zona de oxidação, que pode atingir atē 20 metros de espessura, predominam carbonatos, silicato e óxido de cobre.

Abaixo da zona oxidada predominam sulfetos que são: calcopirita, bornita, pirita e calcosina. Esta não é encontrada na zona primāria.

B.1.1.4 - Gênese da jazida

Diversos autores como Leinz e Almeida (1940), Leinz e Barbosa (1941), Costa Filho (1944), procuraram reconhecer quais seriam as causas da mineralização de cobre nestes sendimentos. 

maioria dos autores a admitir que estas seriam as principais responsā veis pelo processo de mineralização hidrotermal.

Leinz e Almeida (1940) crêm numa origem hidroter mal de média temperatura associada ao magmatismo andesítico, que teria fornecido as soluções mineralizantes em sua fase final de consolidação.

Outros autores, como Melcher e Mau (1960) sugeremser a mineralização relacionada ao granito que ocorre na ārea de Caçapava.

\section{B.1.2 - Geofísica}

\section{B.1.2.1 - Introdução}

Este distrito cuprífero foi o primeiro a ser por nōs estudado geofĩsicamente.

Como jā mencionado anteriormente, os trabalhos de campo foram iniciados por uma fase preliminar desenvolvida em locais de geologia e mineralização conhecidas. 
Sôbre os filões S.Luiz, Feliciano e Oscarino foram medidos perfís transversais, com pontos de medida espaçados de 20 metros, porque êstes filões apresentam não sō as melhores condições geológicas e topogräficas, como também a ausência de condutores artificiais.

\section{B.1.2.2 - Fase preliminar}

Filão S. Luiz

Este filão, que se encontra na parte NE da zona mi neralizada, estā sendo explorado por via subterrânea.

Devido a topografia e sua localização, o filão começou a ser desmontado a partir de cotas inferiores à do seu afloramento em superfície.

Com o desmonte rumo à superfície o minērio ainda não foi totalmente retirado, restando ainda algumas dezenas de metros de altura do filão, além do minērio de profundidade.

A abertura de chaminēs para ventilação dos traba Thos subterrâneos expôs o filão numa secção vertical, onde se pode obser var que a profundidade da zona de oxidação não ultrapassa 20 metros. Sua potência atinge valores superiores à 1 metro com teor de até $2 \%$ de Cu,ou seja, no mínimo, $4 \%$ de sulfeto. 


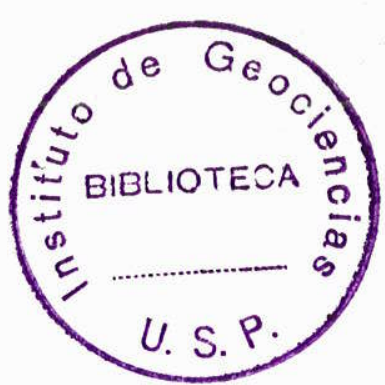

.50 .

0 minērio sulfetado produz anomalias geofísicas, e como a profundidade de alcance do equipamento ē de atē 40 metros, èste filão tinha tôdas as condições para causar anomalias.

Foram assim realizados perfis transversalmente ao filão, sendo 2 perfis com o equipamento E M Gun (figuras 12 e 13) e um terceiro perfil, com o equipamento E M Sharpe, no mesmo local do perfil I (figura 12).

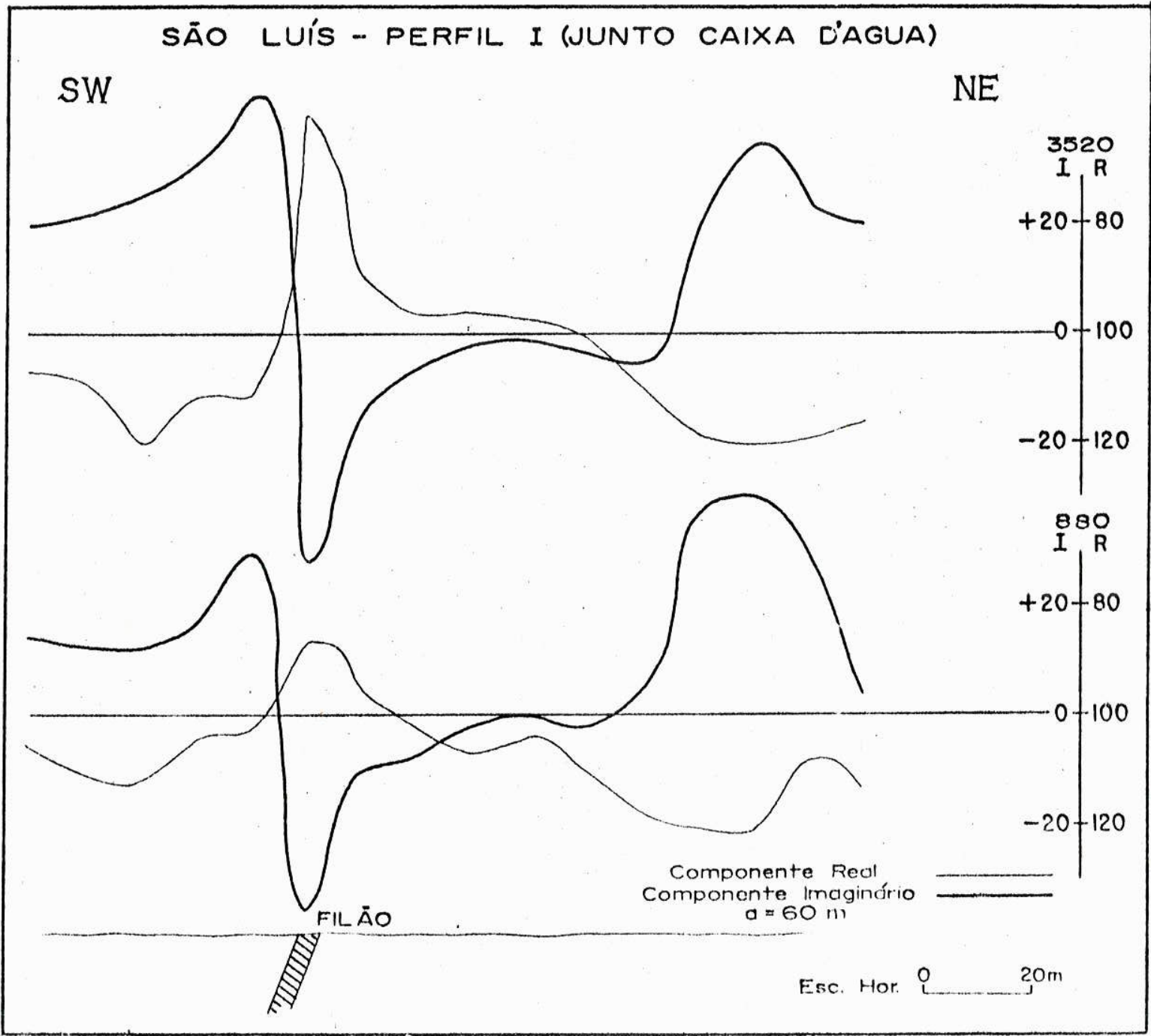

Figura 12 - Perfil I medido sôbre o filão S. Luiz. 
0 perfil medido com o equipamento E M Sharpe revelou uma constância nos valores da inclinação do plano que contēm o vetor campo resultante, ou seja, não indicou qualquer anomalia, nem mesmo em locais onde o primeiro equipamento revela anomalias de algumas dezenas de porcento (pico a pico).

Observando-se a posição dos picos de anomalia dêstes dois perfis, verifica-se que hā uma perfeita concordância entre a sua posição e a posição do filão S. Luiz no terreno.

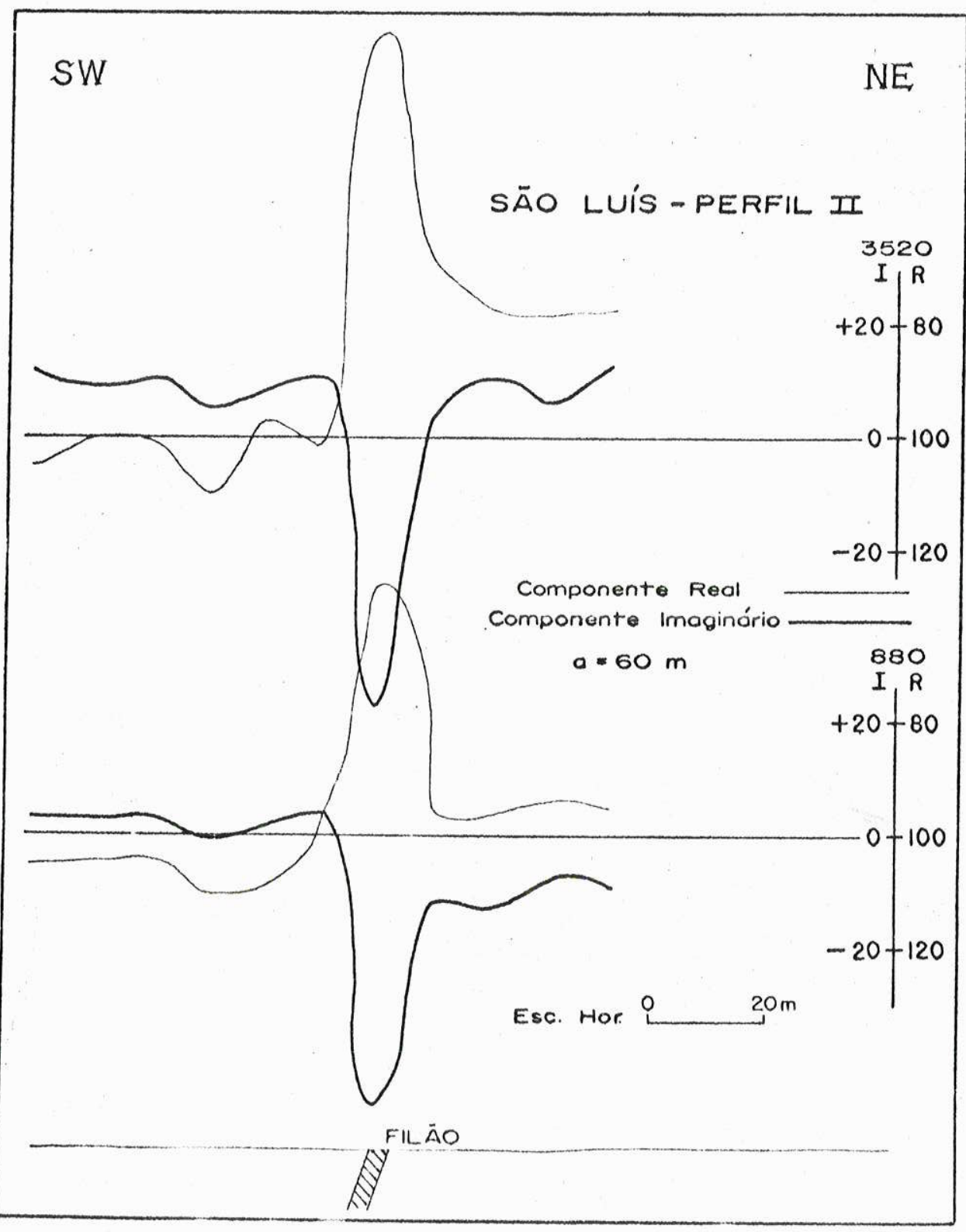

Figura 13 - Perfil II medido sôbre o filão S. Luiz. 
Como o fator indutivo aumenta com a frequência, as anomalias encontradas com a frequência de $3520 \mathrm{c} / \mathrm{s}$ atingem valores mais altos que aquêles com a frequência de $880 \mathrm{c} / \mathrm{s}$.

\section{Fiฺão 0scarino}

0 filão Oscarino aflora à SE da zona mineralizada, em local de topografia ligeiramente ondulada. Destaca-se na superfície sob a forma de um pequeno espigão, devido a cimentação tanto do filão co mo das paredes por sîlica, tornando-o mais resistente à erosão. Mineralō gicamente apresenta-se constituido de quartzo, barita, limonita e em superfície, algumas manchas de malaquita.

A espessura do filão è da ordem de alguns decîme tros. Sondagens executadas pelo DNPM, revelam que em profundidade ocorre fraca mineralização, tendo sido determinados teores de apenas alguns dēcimos de porcento $(0,2-0,4 \% \mathrm{Cu})$.

Os perfis geofísicos medidos através dêste filão, figuras 14 e 15, não mostram qualquer evidência de uma anomalia nîtida. 


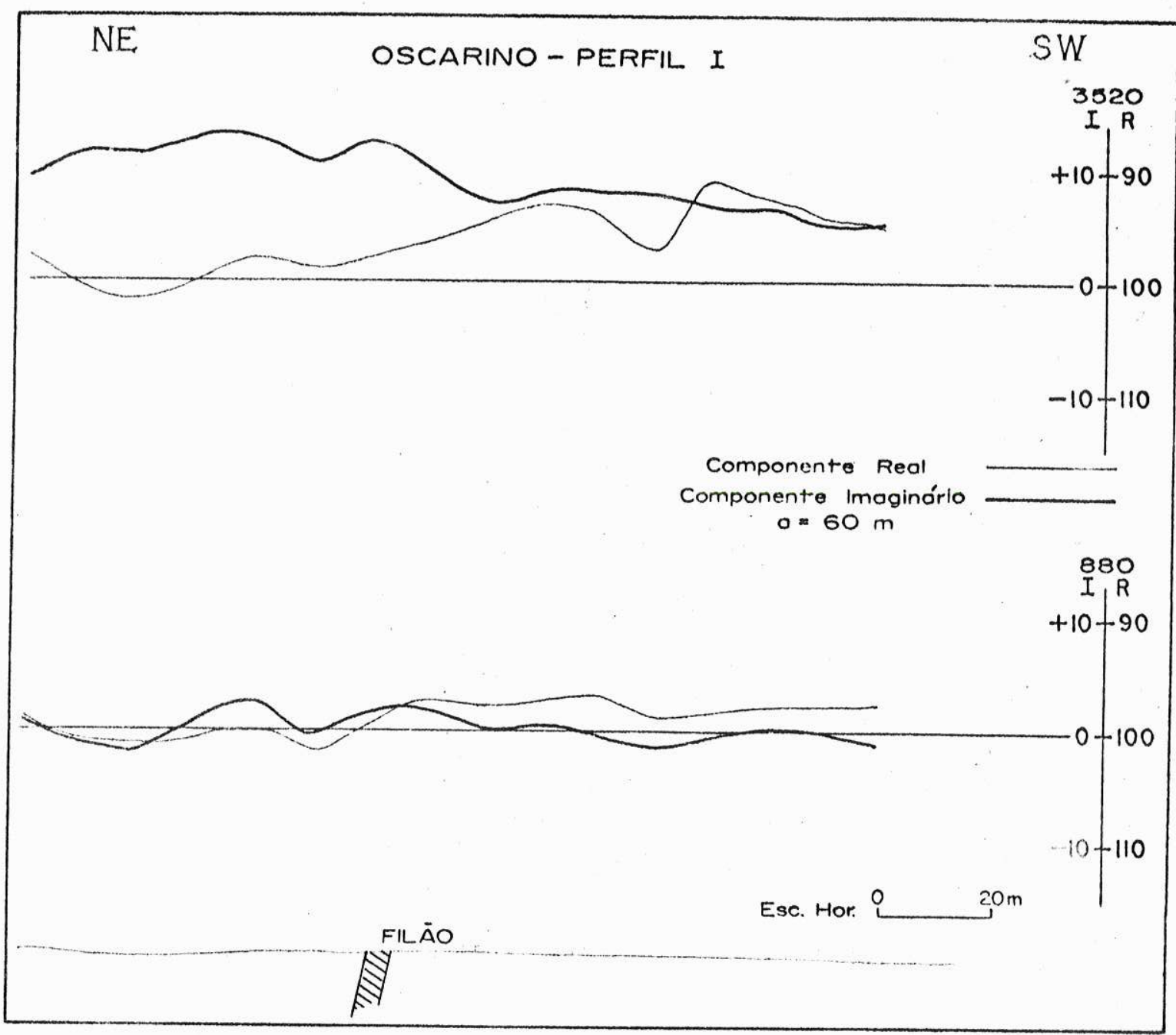

Figura 14 - Perfil I medido sôbre o filão Oscarino.

Sömente o perfil II, na parte medida verticalmente sōbre o filão apresenta alguns valores, em ambas as frequências, que sugerem a existência de uma pequena anomalia. 


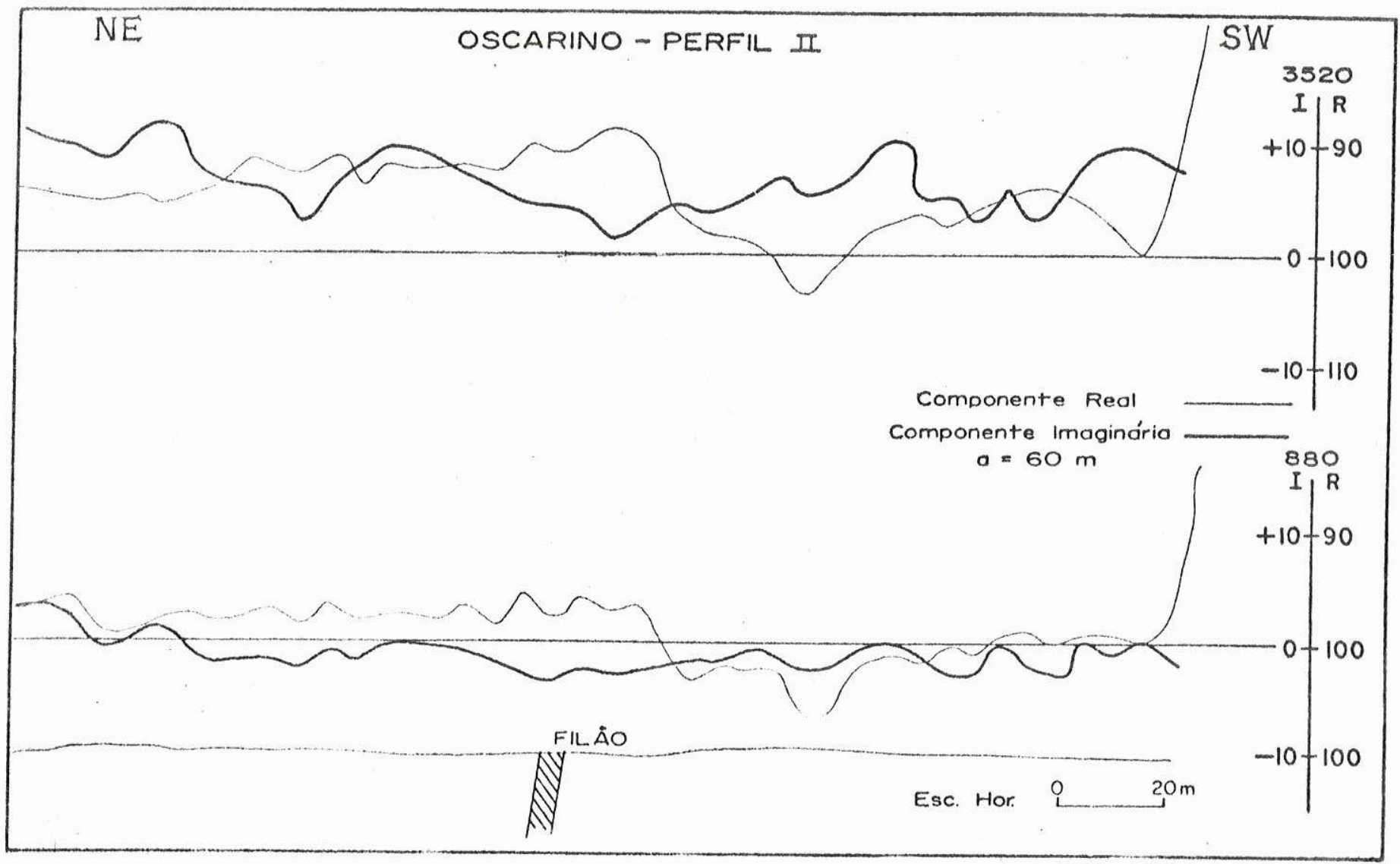

Figura 15 - Perfil II medido sôbre o filão oscarino.

\section{Filão Feliciano}

Mais à sul do filão Oscarino, existe o filão Feli- ' ciano que, devido a silicificação, tambēm se destaca na superfície do ter 
reno. A sua atitude geológica e composição mineralógica ē muito semelhan te ao do filão Oscarino. Sondagens rotativas executadas pelo DNPM revelaram que o teor em cobre dêste filão é inferior ao do filão 0scarino.

Atravēs dêste filão foi medido sōmente um perfil geofísico, que aparece representado na figura 15.

Observa-se que o "back-ground" è relativamente irregular, atingindo variações de mais de 10\% das componentes, porēm isento de qualquer anomalia nítida.

Com os dados obtidos nos perfis medidos atravēs dês tes dois filões, observa-se que nesta região, filões com teores inferiores à $0,5 \%$ de $\mathrm{Cu}$, ou seja sulfetos em quantidade inferior à $2 \%$, não provocam o aparecimento de anomalias quando se emprega o método eletro-magnético-indutivo de fonte mōvel.

\section{B.1.2.3 - Fase de prospecção}

Apōs as experiências executadas nos filões anteri-: ormente mencionados, foi levada a efeito uma prospecção em uma ārea șituada à SE das āreas anteriormente pesquisadas.

Geolōgicamente a região ē constituĩda de sedimen - 
tos arenosos não mostrando qualquer evidência de mineralização.

Foram medidos perfis transversais à estrutura, ou seja, perfis de direção NE-SW, com pontos de medida espaçados de 20 metros.

Dos perfis, que perfazem mais de $28 \mathrm{Km}$, representa mos sōmente o perfil IV, figura 17, uma vêz que o aspecto dos perfis res tantes è pràticamente o mesmo.

Neste perfil IV, aparece uma pequena anomalia, que no terreno coincide com uma sanga. Tal anomalia pode ser explicada como consequência da presença de um solo mais fino, saturado de āgua, cobrindo uma matriz grosseira. Como êste material possui uma condutividade mais elevada que a matriz subjacente, o contraste de anomalia é suficiente pa ra provocar o aparecimento de uma anomalia, principalmente por se tratar de um material condutor existente na superfície do terreno.

Alēm desta anomalia, em outros dois perfis foram en contradas anomalias que quando colocadas em planta aparecem alinhadas se gundo a direção dos falhamentos, coincidindo com a direção do Ribeirão João Dias que neste trecho corre ao longo de uma falha.

Este levantamento, exceto estas poucas anomalias, 
.57.

não indicou qualquer anomalia evidente que pudesse sugerir a presença de uma mineralização. 


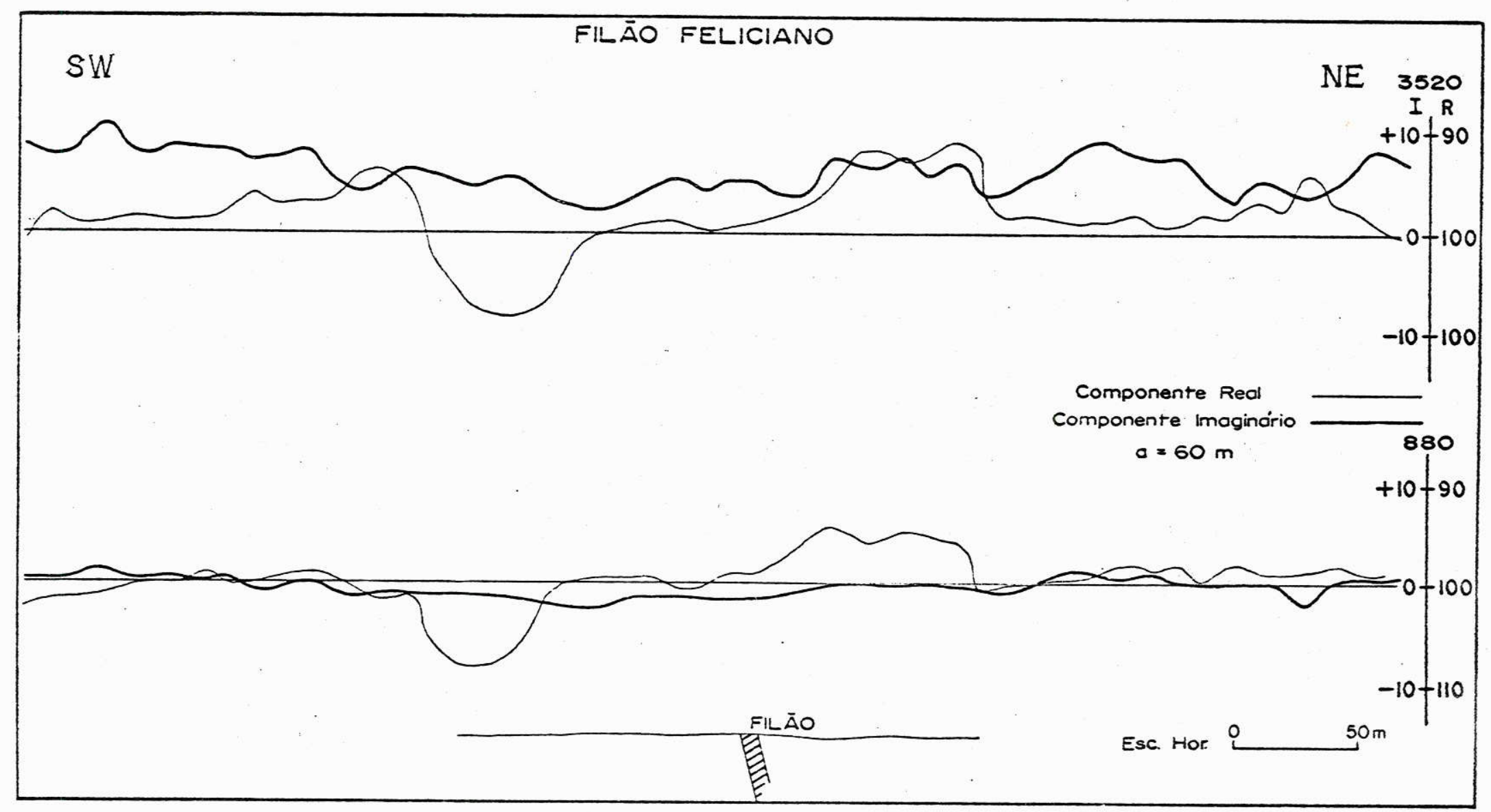

Figura 16 - Perfil geofísico através do filão Feliciano. 


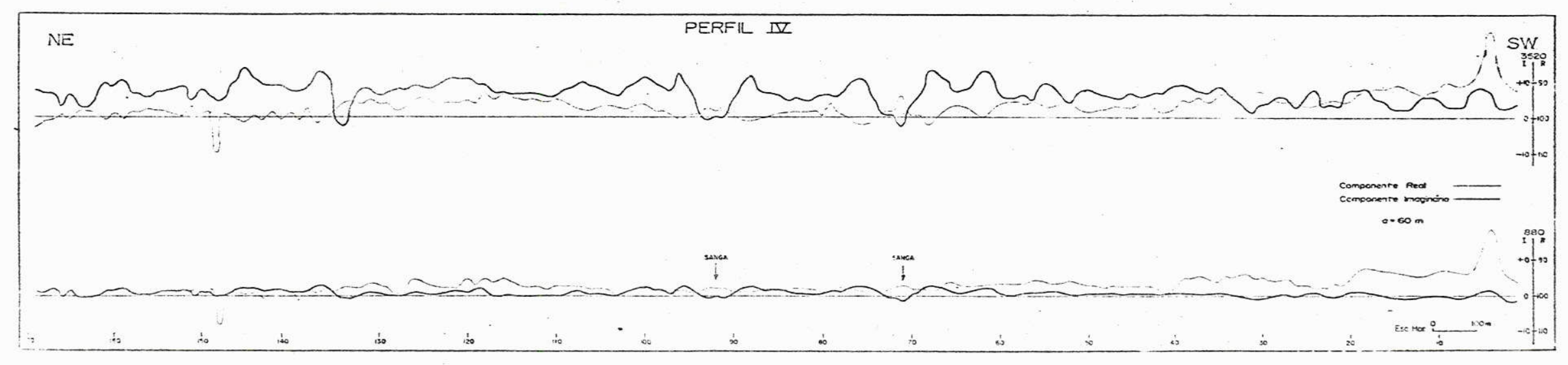

Figura 17 - Perfil geofísico IV. 
.60 .

\section{B.2 - CARAIBA}

\section{B.2.1 - Geologia}

\section{B.2.1.1 - Introdução}

A ārea da Mina da Caraíba acha-se localizada entre os paralelos 109 e 129 Sul e os meridianos 390 e 409 0este, em plena zona da caatinga, no Nordeste Brasileiro.

A topografia da ārea ē plana, quebrada localmentepelo serrote de Caraíba, situado à NW da sede da fazenda.

Hidrogrāficamente, pertence à Bacia do São Francis co, sendo cortada pelo cōrrego Curaçā, que corre sōmente alguns dias, no perīodo das chuvas, correspondente aos mêses de outubro à abril.

0 regime das chuvas $\overline{\mathrm{e}}$, em geral, torrencial, poden do frequentemente em um só dia, precipitar atē $25 \%$ da precipitação anual total, que ē da ordem de $500 \mathrm{~mm}$.

Os rios possuem escoamento elevado, associado $\bar{a} u-$ 
ma alta evaporação provocando a precipitação dos sais dissolvidos, o que dā carater salobro à maior parte da água armazenada nas fendas das ro chas.

A vegetação è tîpica de clima semi-ārido e ē rica em cactāceas.

0 clima, com duas estações, uma sêca, onde durante o dia a temperatura ultrapassa 350 C cainda à noite para abaixo de 2009, e outra das chuvas, que ocasionalmente pode deixar de existir.

\section{B.2.1.2 - Geologia Regional}

Observando-se o mapa geológico do Brasi1, DNPM-1966, a região da Caraíba localiza-se no Prē-Cambriano Gnaissico Indiviso.

As rochas da região constituem-se predominantemente de gnaisses-migmatîticos, pertencentes ao Grupo Uauā. Apresentam faixas melanocrāticas com concentrações de minerais ferro-magnesianos e fai xas leucocrāticas constituidas de quartzo e feldspatos. Nos gnaisses são comuns lentes de anfibolitos.

A estrutura predominante dos gnaisses ē N-S, com mergulhos prōximos à vertical. Concordantemente com os gnaisses afloram- 
corpos de granito rōseo, de granulação fina. As vêzes, mostram relaçõesintrusivas com o gnaisse encaixante, envolvendo e absorvendo fragmentosde gnaisse. São comuns pequenos diques que partindo do corpo granítico penetram nas encaixantes.

\section{B.2.1.3 - Geologia local}

Segundo Coutinho e Barros Gomes (1964), na região da Mina Caraỉba o complexo gnaissico, é cortado por um conjunto de rochas ultrabāsicas metamorfizadas, que apresentam estrutura E-W, ou seja,trans versal à direção geológica regional.

Estas rochas constituem-se de um nūcleo básico cen tral, rodeado de uma zona intermediāria que passa gradualmente ao gnaisse regional. Esquema semelhante jā foi reconhecido por Leinz (1948).

- Complexo Bāsico Central.

E constituido principalmente de rochas bāsicas metamorfizadas de elevado grau de metamorfismo, tais como granulito norîti co, piroxenito, biotitito,hornblendito e diopsidito.

0 granulito noritico e piroxenito possuem distri buição mais ampla e os demais tipos litolōgicos ocorrem apenas em āreasrestritas. 
.63.

No granulito norítico predominam labradorita e hiperstēnio alēm de biotita, diopsídio e hornblenda. No piroxenito o mineral dominante è o hiperstênio.

- Zona Intermediāria

Rodeando o complexo bāsico central ocorre uma zona intermediāria, de transição, com espessura de atē 200 metros, constituida de rochas quartzo-feldspäticas representadas por gnaisses e rochas "igneas", resultantes da ação metassomātica sōbre os granitos rōseos re gionais.

A direção predominante dos falhamentos, que localmente foram intensos, ē aproximadamente $\mathrm{N}-\mathrm{S}$, com variações para NW e NE e mergulhos acentuados sempre para $E$.

\section{B.2.1.4 - Mineralização}

Os piroxenitos do nūcleo central e tambēm as ro chas ricas em biotita da zona intermediāria serviram de hospedeiros ao processo mineralizador, que resultou na formação de sulfetos dissemina dos em vênulas e pequenos "stock-works". Os sulfetos dominantes são calcopirita, bornita, pirita e pequena quantidade de arsenopirita.

A zona dos minērios oxidados, com predomināncia de malaquita pode atingir atē 30 metros de profundidade. 
.64 .

\section{B.2.2 - Geofísica}

\section{B.2.2.1 - Introdução}

Tal como em Camaquã, tambēm na Caraība, os traba Thos de campo foram divididos em duas fases: fase preliminar e de pros peç̧ão.

$\mathrm{Na}$ fase de prospeç̧ão foi executado um levantamento pormenorizado de uma ārea restrita, de algumas dezenas de hectares.

Foi empregado apenas o equipamento E M Gun da ABEM, mantendo-se 0 espaçamento de 60 metros entre as bobinas receptora e trans missora, com pontos de medida espaçados de 20 metros.

As ilustrações das anomalias geoquĩmicas apresenta das neste trabalho, foram confeccionadas a partir de levantamentosgeoqui micos realizados pelo pessoal técnico da "Caraíba Mineração Metalurgia", bem como parte das informações geolōgicas aqui mencionadas foram forneci das pelos geōlogos da referida Emprēsa.

\section{B.2.2.2 - Fase preliminar}

Durante esta fase preliminar foram medidos perfisem áreas que apresentam uma das seguintes características: 
a) - ārea com anomalia geoquĩmica

b) - ārea com corpos de minērio

c) - ārea sem anomalia geoquīmica

d) - ārea com anomalia geofísica determinada pelo método do potencial induzido.

a) - ārea com anomalia geoquímica

Dentre os perfis medidos em āreas de anomalia geoquímica apresentamos os perfis III e $X$.

No perfil III, medido em ārea onde foram constata das anomalias geoquĩmicas que atingem atē 165 ppm Cu acima da média regio nal, aparecem dois picos de anomalia, sendo que um aparece em L-101 e outro em L-103.

As anomalias correspondentes à frequência de 3520 c/s são mais desenvolvidas pois o fatorindutivo aumenta com a frequência, Em L-101 existe no terreno a extremidade de uma lente de granito bem como uma anomalia geoquîmica. Em L-103, as rochas aflorantes são bāsicas e a presença de anomalias geoquímica e geofísica sugerem a presença de mi nério sulfetado. 


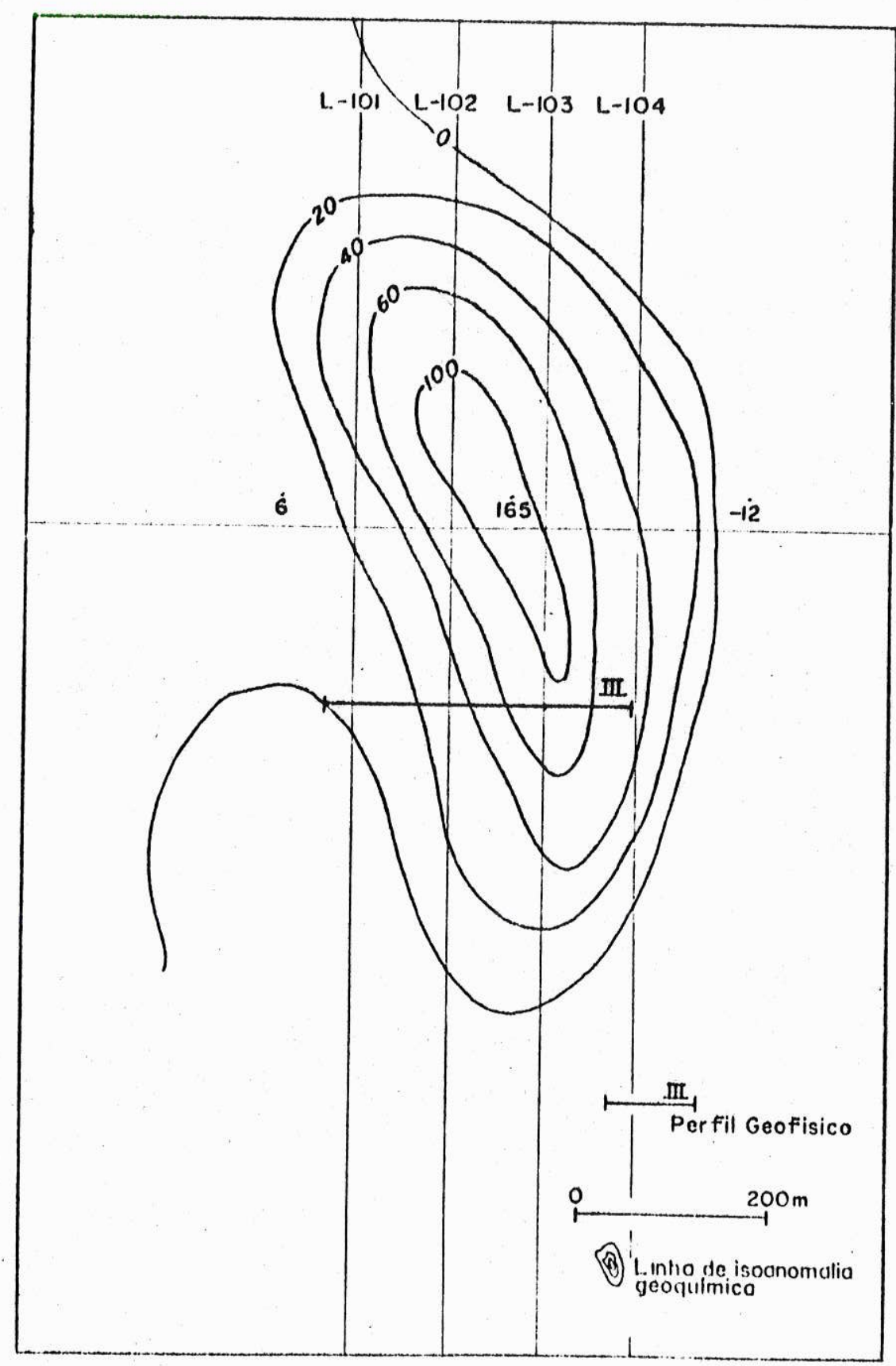

Figura 18 - Mapa de isoanomalia geoquímica e a posição do perfil III. 


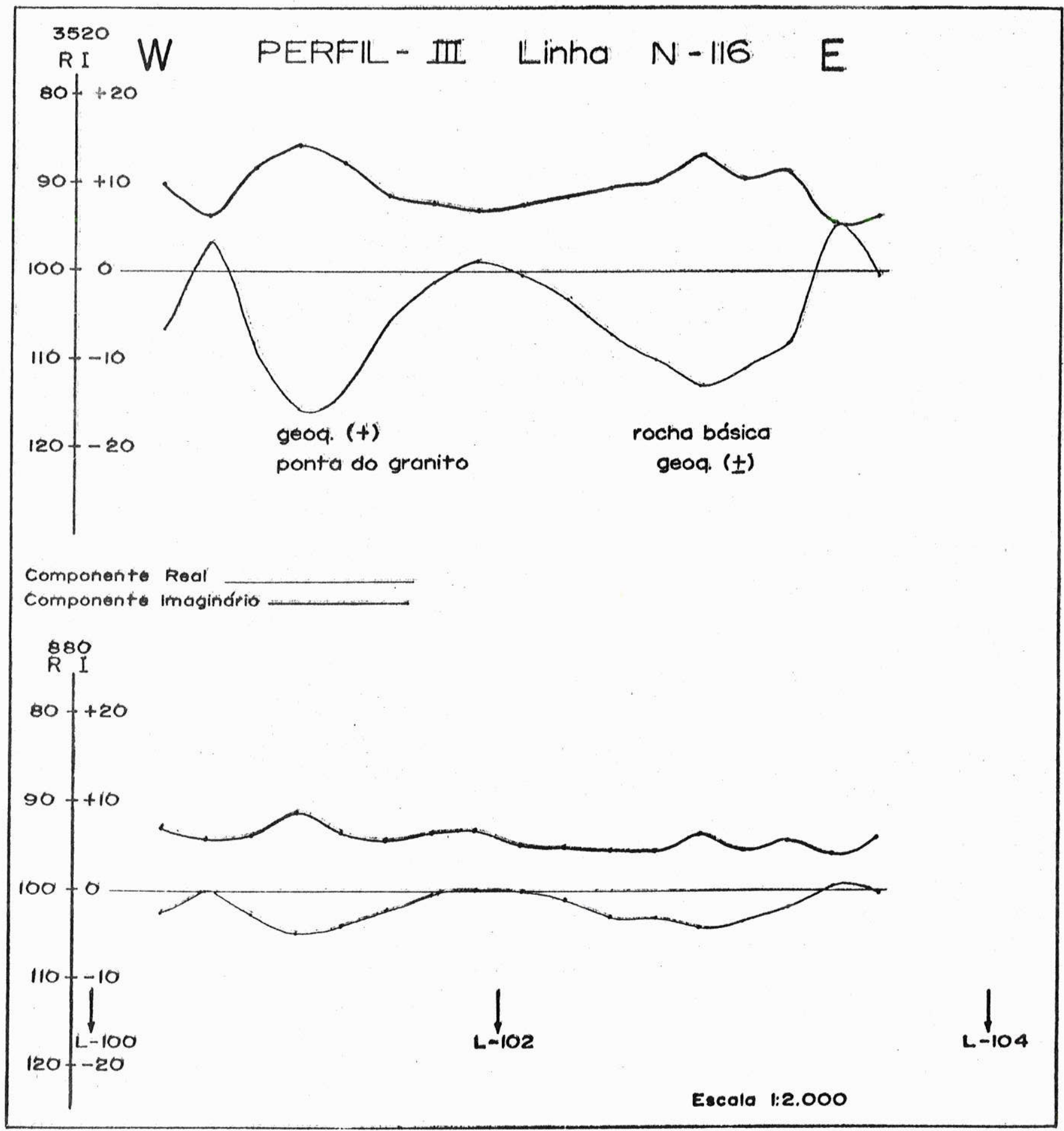

Flgura 19 - Perf11 geofísico III 


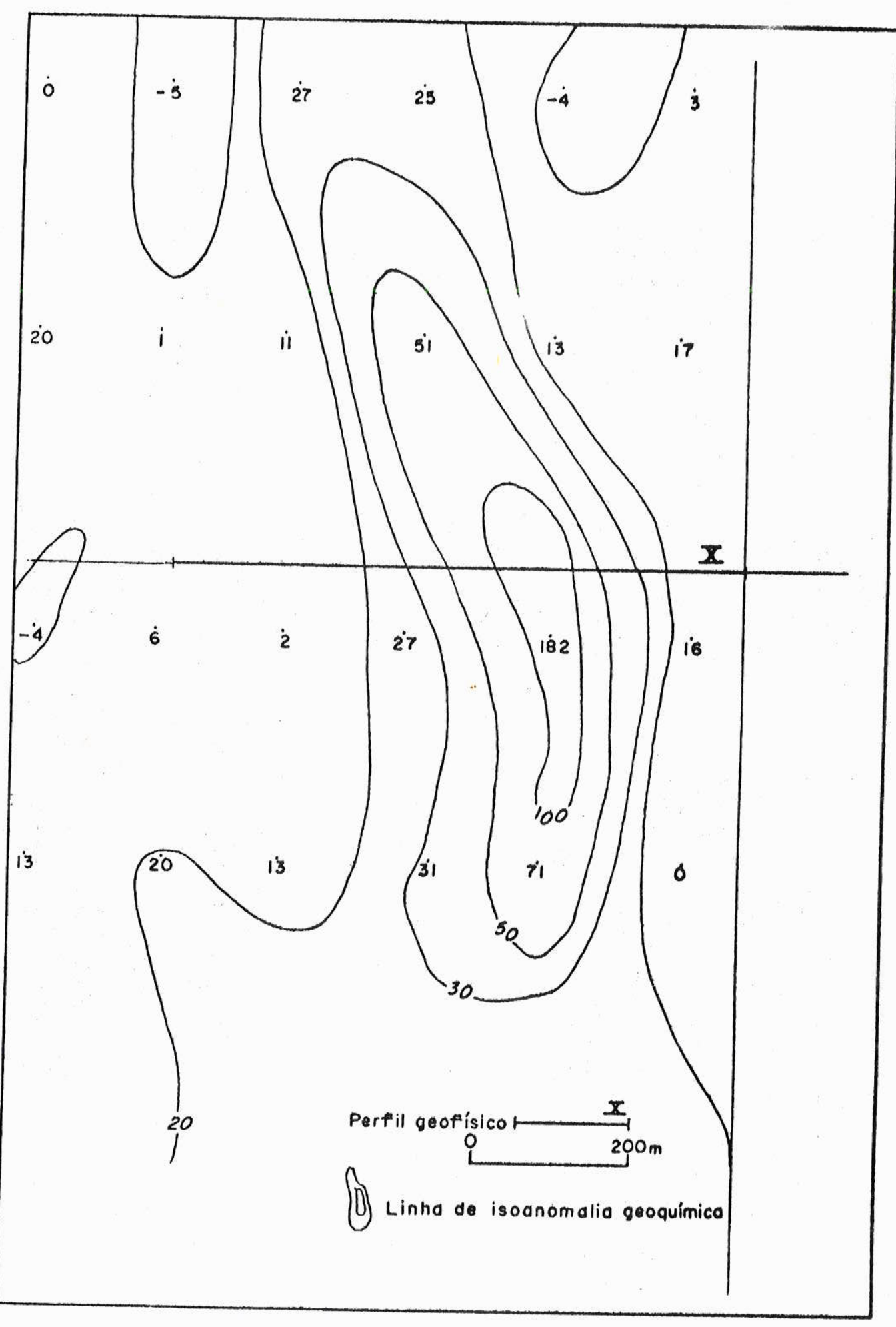

Figura 20 - Mapa de isoanoma1ia geoquïmica e posição do perfil X. 


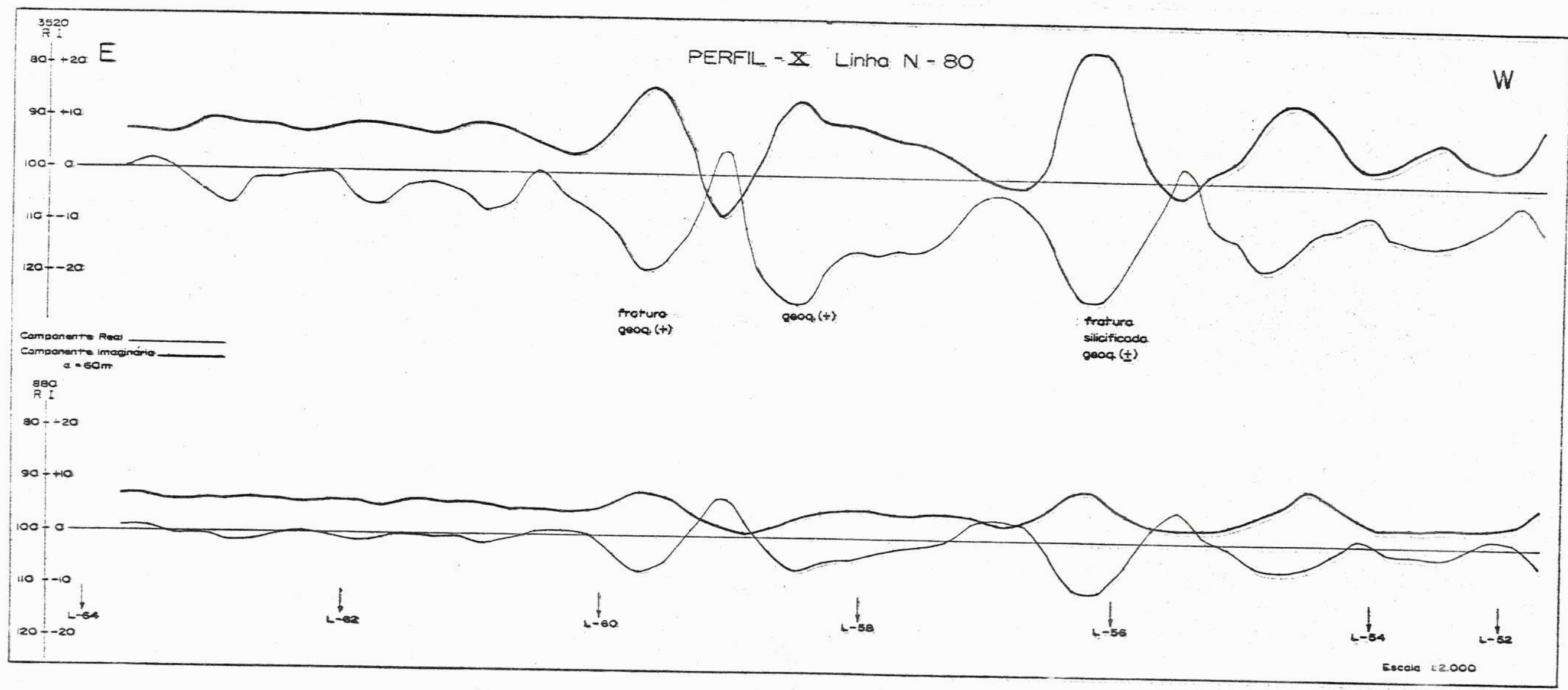

Figura 21 - Perfil geofísica $X$. 
.70 .

0 perfil $X$, apresenta tambēm anomalias geofísicásassociadas à anomalias geoquīmicas. Neste perfil hā uma concordância entre as fraturas e a anomalia geofísica, anomalia esta bem característica em ambas as frequências.

Os valores encontrados com a frequência de $880 \mathrm{c} / \mathrm{s}$, mostram anomalias em locais de fratura e anomalia: geoquímica, enquantoque permanecem prāticamente inalterados, principalmente na parte $E$, ou seja, entre L-60 e L-64.

Na frequência de $3520 \mathrm{c} / \mathrm{s}$ os valores são bem mais oscilantes, tomando porēm a forma típica de uma anomalia em L-59,5, L-58,5 e L-56.

Se compararmos as amplitudes das anomalias geofísi cas encontradas em L-56 e L-59,5 com o tipo de fratura e valor da anomalia geoquímica, verifica-se que em L-56, onde a fratura se encontra sili cificada e os valores geoquỉmicos são inferiores aos de L-59,5, e anomalia geofísica é maior. Tal fato pode ter as seguintes causas:

a) - a fratura contēm água salobra.

b) - existe mineralização de sulfeto em profundidade em L-56

c) - a proximidade das duas zonas mineralizadas de L-58,5 e L-59,5 se influenciam mūtuamente, di minuindo o valor individual das anomalias. 


\section{b) - ārea com corpos de minērio}

Na ārea da Mina Caraība prōpriamente dita foram medidos, dentre outros, os perfis I e II.

0 perfil I apresenta em ambas as frequências anomalias que atingem dezenas de porcento.

A parte do perfil medido sôbre o minērio, ou sejaentre L-116 e L-108, apresenta um afastamento entre as componentes I e $R$, em ambas as frequências, semelhantes ao comportamento da anomalia consta tada em laboratōrio, quando se mede sôbre uma placa horizontal, como pode ser visto na figura 11, inclusive o aumento da anomalia ao se chegar na extremidade da placa.

As anomalias presentes na parte $W$ são devidas ãs lentes de granito.

Na extremidade E, prōximo:ä $L-111$, onde ainda exis tem anomalias geoquĩmicas, ocorre uma fratura que provoca a anomalia geo física.

0 perfil II, medido à sul do perfil I, apresenta va lores e aspectos que diferem bastante do perfil anterior. 
.72 .

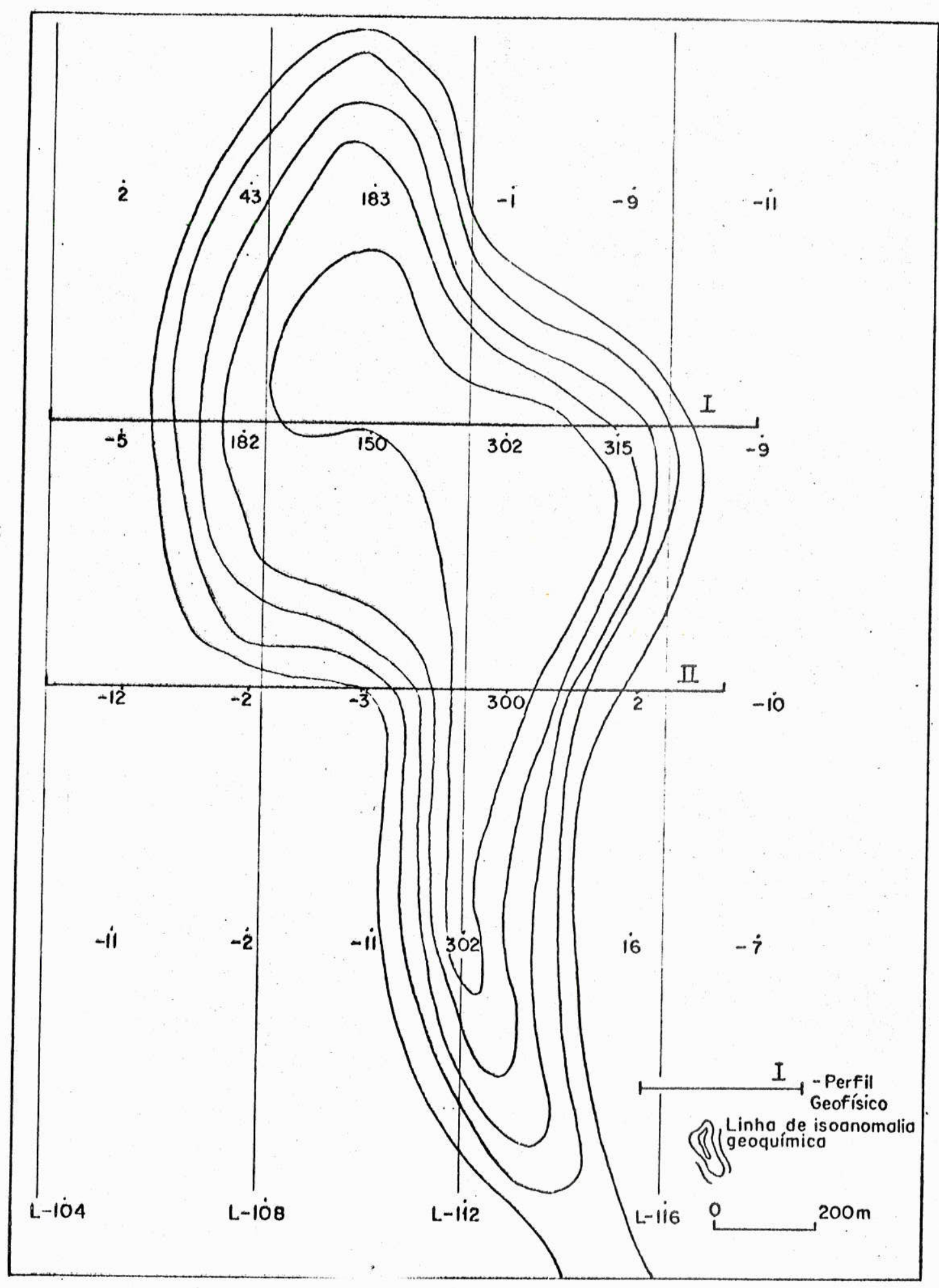

Figura 22 - Mapa de isoanomalia geoquimica e posição dos perfís I e Il. 


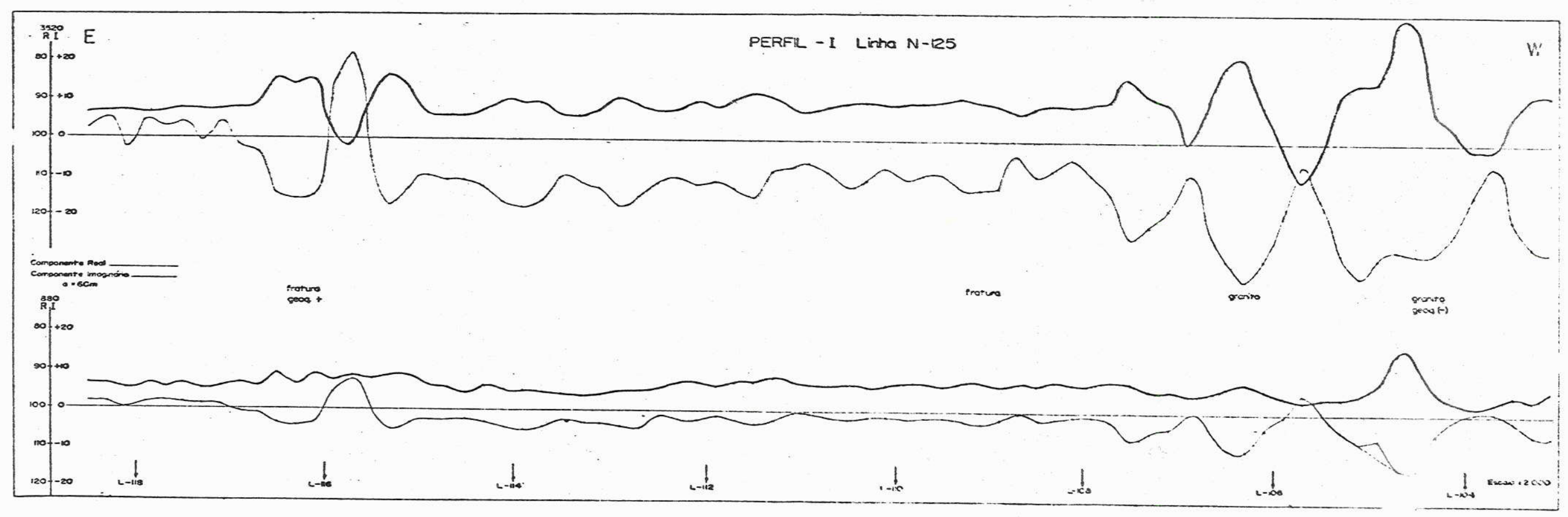

Figura 23 - Perfil geofísico I. 


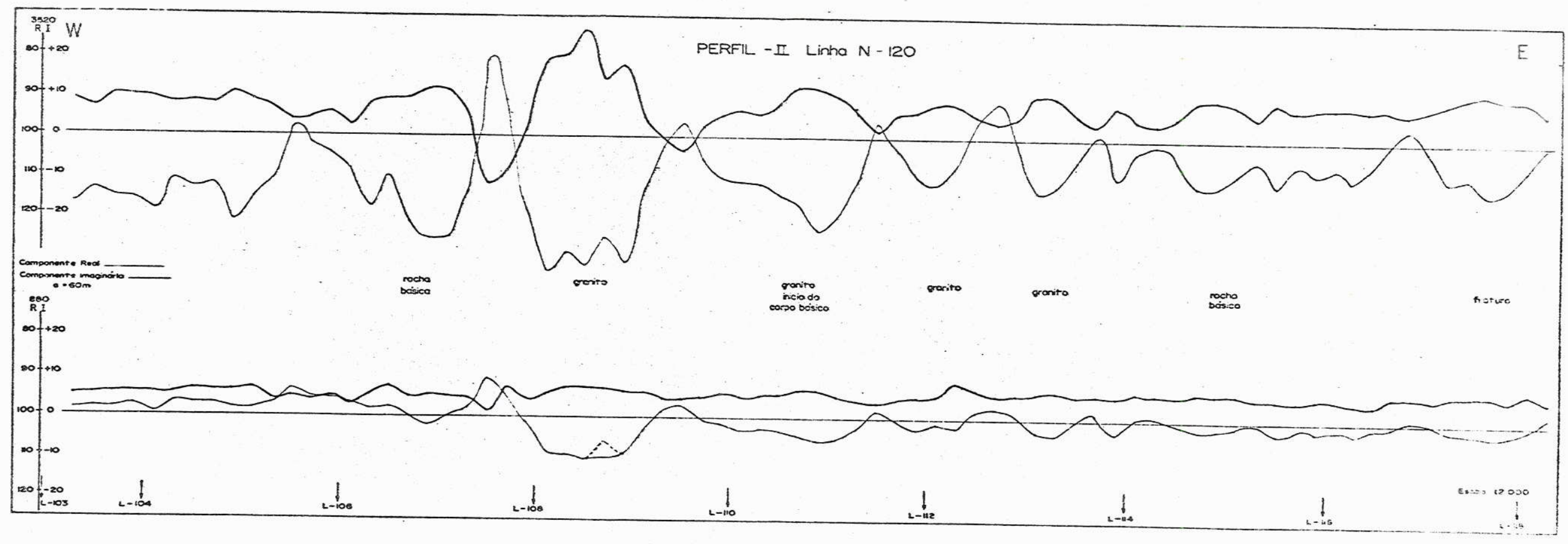

Figura 24 - Perfil geofísico II. 
Constante neste perfil è a anomalia em L-109, causa da pelo granito.

Na parte correspondente ao corpo de rochas bäsicas, à $E$ de L-114, tambēm ocorre o afastamento entre os valores das duas compo nentes I e R, tal como no perfil I. A fratura em L-118 provoca anomalia, porēm sōmente na frequēncia elevada.

\section{c - ārea sem anomalia geoquĩmica}

Para verificar o comportamento do campo eletro-mag nético induzido em local sem anomalia geoquímica foi medido o perfil XII.

Neste perfil, nota-se que a componente que menos $\underline{0}$ freu oscilações foi a componente $R$ da frequência de $880 \mathrm{c} / \mathrm{s}$, que se manteve prāticamente inalterada durante todo o perfil.

Mesmo na frequência elevada, as variações de $\mathrm{R}$ são reduzidas, não acompanhando as variações anōmalas da componente I, exceto em L-105.

A componente I, em ambas as frequências, sofre oscilações de poucas dezenas de porcento. 
.76 .

Como na ārea não foram encontradas anomalias geo quỉmicas, pode-se admitir que as oscilações são devidas a:

a) - zonas de concentração de magnetita nos grani tos e gnaisses

b) - zonas de fraturas contendo soluções salinas

c) - zonas de concentrações salinas na superficiedo terreno.

d) - ārea com anomalia geofísica determinada pelo método do potencial induzido

A norte da ārea da Caraíba, em Surubim, foram medi dos alguns perfis, dos quais apresentamos o perfil XXX.

Com base em trabalhos geofísicos aî executados anteriormente, para os quais foi utilizado o método do potencial induzido, em āreas selecionadas, foram abertas trincheiras, poços e realizadas son dagens.

Os resultados obtidos foram diversos. Em alguns lo cais, onde havia anomalia geofísica, os trabalhos de prospecção revelaram a presença de zonas mineralizadas, como assinaladas no perfil XXX. Em ou tros locais porēm, mesmo com anomalias geofĩsicas bem caracterizadas, não foi encontrado qualquer sinal de mineralização. 
Na extremidade $W$, do perfil XXX, nas componentes I e $\mathrm{R}$ da frequência de $3520 \mathrm{c} / \mathrm{s}$ aparecem valores extremamente elevados, que estão ausentes na frequência de $880 \mathrm{c} / \mathrm{s}$.

A $W$ de FS-20, o perfil foi medido numa região cober ta por aluviões trazidos pelos rios que aî correm durante a época das chu vas; Como os rios não são perenes e frequentemente formam pequenas lagoas que se secam no perīodo da estiagem, hã a precipitação dos sais dissolvidos na āgua.

Alguns dos sais precipitados devem ser higroscōpi cos, retendo uma certa umidade, que confere ao solo uma alta condutividade (baixa resistividade).

Assim sendo, èste material superficial de alta condutividade situado sôbre um substrato isolante, que ē a rocha fresca, pro voca a concentração das correntes alternadas induzidas nesta capa superfi cial ("skin effect"). A concentração destas correntes é diretamente pro porcional à frequência utilizada. Deste modo, quanto maior a frequência da corrente, tanto menor a penetração das correntes induzidas.

0 que se nota na parte $W$ dêste perfil XXX, ē o re sultado do "skin effect" associado ao aumento de indução ocasionando uma falsa anomalia, que porém não aparece na frequēncia de $880 \mathrm{c} / \mathrm{s}$. 
.78 .

0s demais perfis obtidos nesta ārea apresentam 0 mesmo fenômeno quando medidos em āreas cobertas por depōsitos de rios têm porārios. 


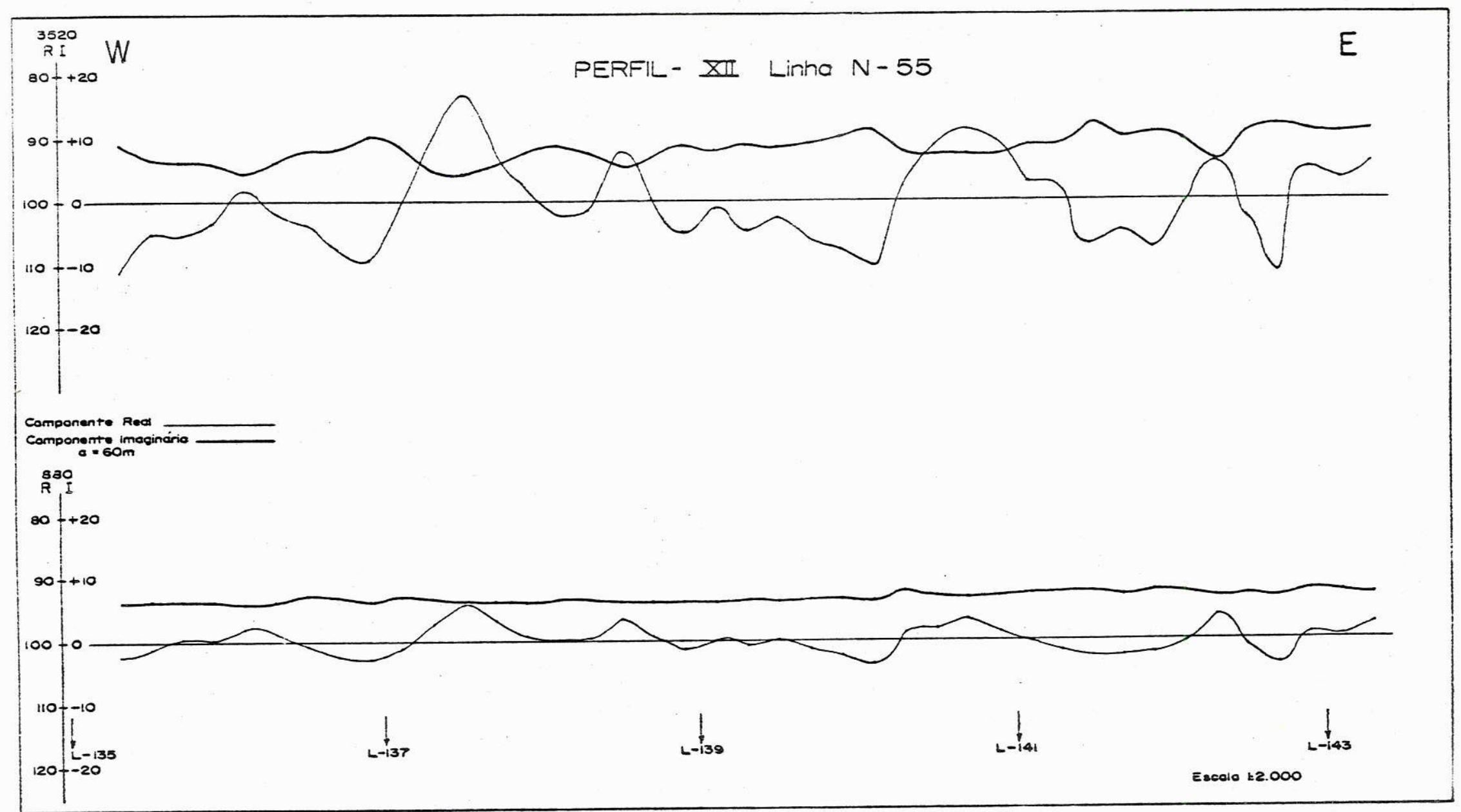

Figura 25 - Perfil geofísico XII 


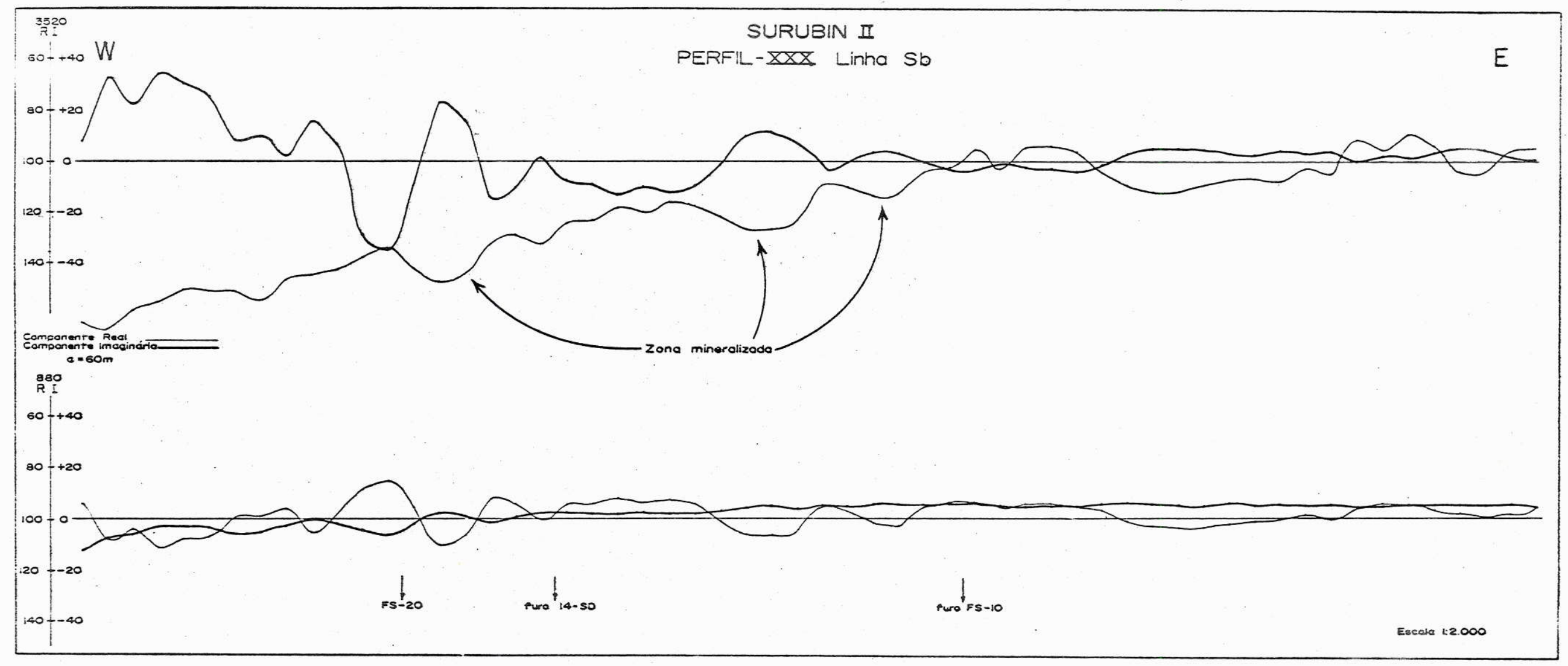

Figura 26 - Perfil geofísico $\mathrm{xxx}$. 


\section{B.2.2.3-Fase de prospecção}

Com a experiência obtida durante os trabalhos da fa se preliminar, foi executado um levantamento pormenorizado de uma ārea de algumas dezenas de hectares.

Nesta ārea ocorre uma anomalia geoquīmica, onde são encontrados valores de atē $250 \mathrm{ppm} \mathrm{Cu}$ acima da mēdia regional, como pode ser observado na figura 27.

Nesta ārea foram executados perfis E-W, espaçados de $50 \mathrm{~m}$, perpendicularmente à estrutura geolōgica, com pontos de medida distanciados de 20 metros.

Nos perfis foram assinaladas as anomalias, que foram arbitrāriamente divididas em três grandezas, 1, 2 e 3, respectivamente, segundo a sua extensão e amplitude.

0 mapa de anomalias geofísicas mostra uma série de anomalias das quais uma estā presente em todos os perfis, entre L-30 e L-31, numa direção aproximadamente N-10-W.

Nos vārios perfis aparecem outras anomalias, sem apresentarem a constância daquela acima referida. 
.82.

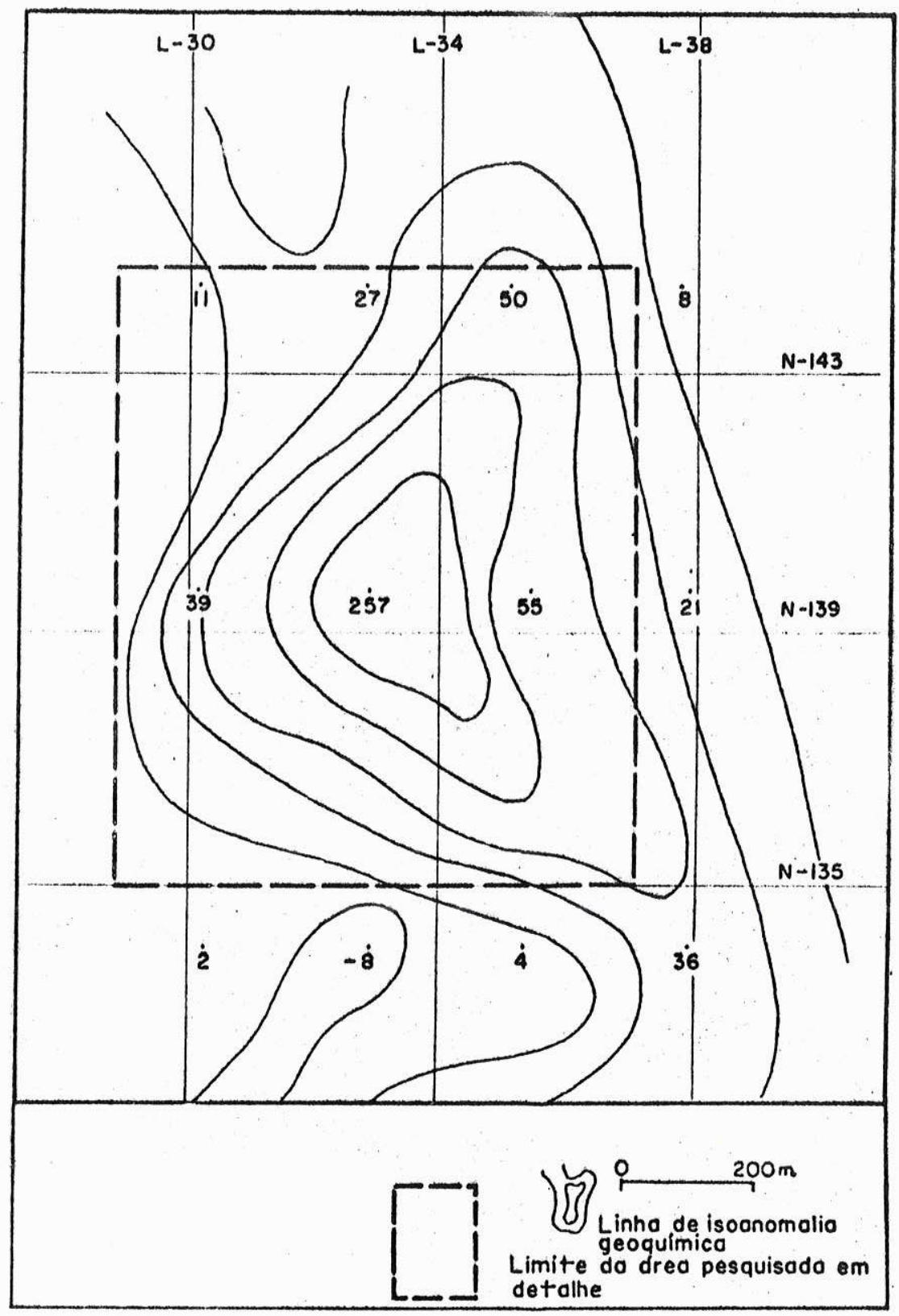

Figura 27 - Mapa geoquímico regional e delimitação da ärea estudada em pormenor 


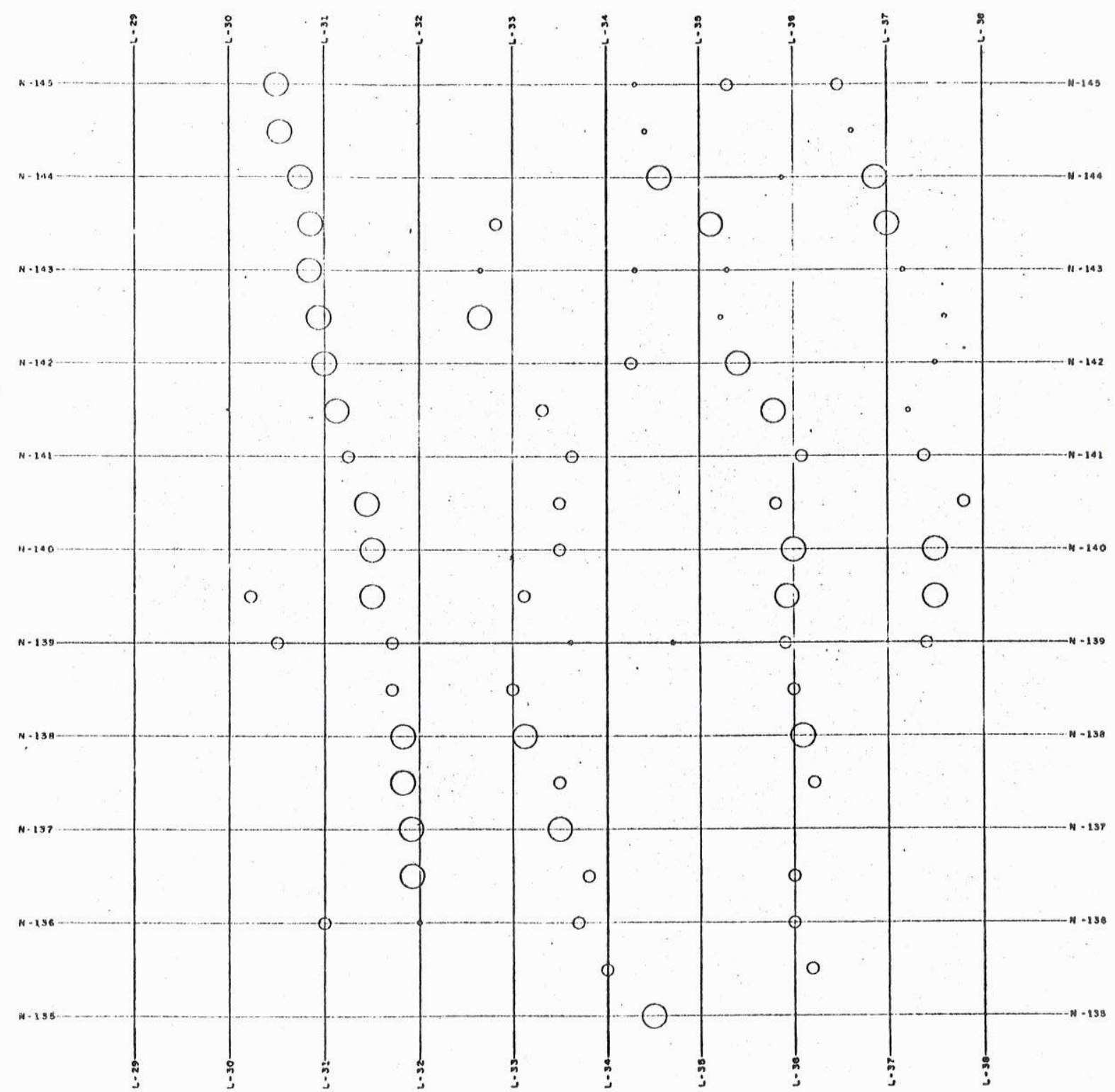

Figura 28 - Posição das anomalias e suas grandezas 
.84 .

observações geológicas determinaram que a atitudedas rochas é aproximadamente $\mathrm{N}-\mathrm{S}$, com mergulhos acentuados para $\mathrm{E}$, o que è também corroborado pelo aspecto das curvas de anomalia (vide figura 11).

Comparando-se a posição das anomalias geofísicas e a posição das anomalias geoquĩmicas obtidas por um levantamento pormenorizado (não apresentado no presente trabalho), verifica-se que hā um des locamento relativo entre a posição das duas anomalias, que deveriam ser coincidentes geogräficamente. As anomalias geofísicas encontram-se des $\underline{0}$ cadas rumo à $w$.

Isto levou a supor que o corpo causador da anoma lia geofísica não è o mesmo que causa a anomalia geoquīmica.

A fim de procurar verificar a causa das anomaliasgeofísicas existentes na ārea, foram executadas sondagens rotativas aber tas trincheiras, que revelaram a presença de uma lente contendo grafitae em profundidade, um corpo bāsico fracamente mineralizado.

A lente contendo grafita ocorre até a superfície (coberta por solo residual), nos pontos onde foram encontradas as anomalias geofísicas, e possui um mergulho de cêrca 70 p para leste, confirman do as indicações anteriormente obtidas. 
0 corpo básico fracamente mineralizado, encontra-se neste local, numa profundidade maior que 40 metros.

Os testemunhos de sondagem mostram que alēm da calcopirita, ocorre frequentemente pirita e eventualmente arsenopirita.

0 teor de cobre contido nestas rochas raramente ultrapassa $0,5 \% \mathrm{Cu}$, ou seja, uma quantidade de sulfetos de $2-3 \%$, a qual è su ficiente para provocar o aparecimento de anomalias geofísicas, como as ob servadas no restante da ārea.

\section{B.2.3 - Aplicação do "Trend Surface Analysis"}

\section{B.2.3.1 - Introdução}

Com a finalidade de se verificar o uso de aplicação do "trend surface analysis" como metodologia na interpretação de dados ob tidos atravēs da aplicação do método eletro-magnētico, foi feito um en saio utilizando-se os dados obtidos no levantamento pormenorizado.

Nesta ārea foram medidos 20 perfis, espaçados de 50 $\mathrm{m}$, com pontos de leitura distantes de $20 \mathrm{~m}$, obtendo-se um total de aproxi madamente 900 pontos de medida. Estes pontos representam 3.600 informa ções, uma vez que são medidas as componentes R e I das frequências de 880 e $3520 \mathrm{c} / \mathrm{s}$, respectivamente. 
.86 .

\section{B.2.3.2 - Cālculo}

Como o programa era limitado na época do tratamento, foram aproveitados somente os dados obtidos em perfis espaçados de $100 \mathrm{~m}$, o que representam cêrca de 450 pontos de medida. A malha de pontos perfazassim um retīculo de $100 \times 20$ metros.

0s cālculos das superfícies apresentam baixos fatôres de correlação, que não ultrapassaram 40\%, em consequência da elevada flu tuação nos valores medidos no campo.

As superfícies não ultrapassaram a do 30 graú, pois a partir do cālculo da superfície do 40 grau, foi encontrada indetermina ção.

0 mapa do "trend surface analysis" não è muito con clusivo, pois estā prejudicado pelo baixo fator de correlação. Assim sendo, procurou-se estudar e interpretar não os mapas, mas sim os resĩduos, procu rando, por meio de seu agrupamento e distribuição verificar a sua utilização.

\section{B.2.3.3 - Mapa dos resíduos}

Observando-se a figura 9 , nota-se que os valores anô 
malos são aquêles onde a componente I atinge valores inferiores a $0 \%$, ou seja, negativos, e a componente $\mathrm{R}$, valores inferiores a $100 \%$.

Como o espaçamento entre as bobinas era de $60 \mathrm{~m}$, e o espaçamento entre os pontos de medida de $20 \mathrm{~m}$, há pelo menos 2 pontosde medida entre as bobinas quando estas se deslocam. Por menor que seja um corpo, e mesmo que duas medidas $R_{7} T_{1}$ e $R_{4} T_{4}$ caîssem verticalmente sôbre o corpo, hā sempre duas posições $R_{2} T_{2}$ e $R_{3} T_{3}$ que estão com o corpo si tuado entre as bobinas $T$ e R.

Foram assim selecionados grupos de no mĩnimo 2 valores negativos sucessivos de resíduos, admitidos como sendo anomalia.

Como uma anomalia é expressa por valores inferio res à $0 \%$ para I e inferiores a 100\% para $\mathrm{R}$, em ambas as componentes das duas frequências, pelo menos em princīpio, admitiu-se primeiramente como anomalia o trecho do agrupamento dos resíduos comum a duas componentesde uma mesma frequência, por exemplo I e R de $880 \mathrm{c} / \mathrm{s}$.

Depois de selecionado o trecho anômalo comum a ambas as componentes de uma mesma frequência, foi o mesmo realizado para as componentes da outra frequência.

Isto feito, foram delimitados os trechos anômalos- 
.88.
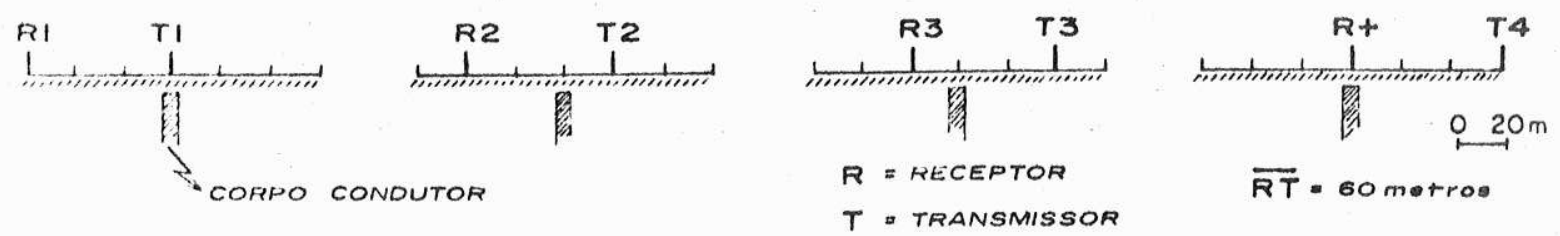

Figura 29 - Posição relativa de $\mathrm{R}$ e $\mathrm{T}$ e o corpo condutor.

comuns, agora, a ambas as componentes das duas frequências, resultando disto o mapa da figura 30 .

Verifica-se que êste mapa assemalha-se muito ao da figura 28 , o que permite concluir que a técnica do "trend surface analysis" ē aplicavel quando se utiliza o resĩduo, podendo-se delimitaras äreas anômalas.

Como a posição geogräfica das anomalias ē de grande importância, èste mētodo ē de grande valia na prospecção de āreas extensas, pois è grande o volume de dados a ser tratado. 
.89.

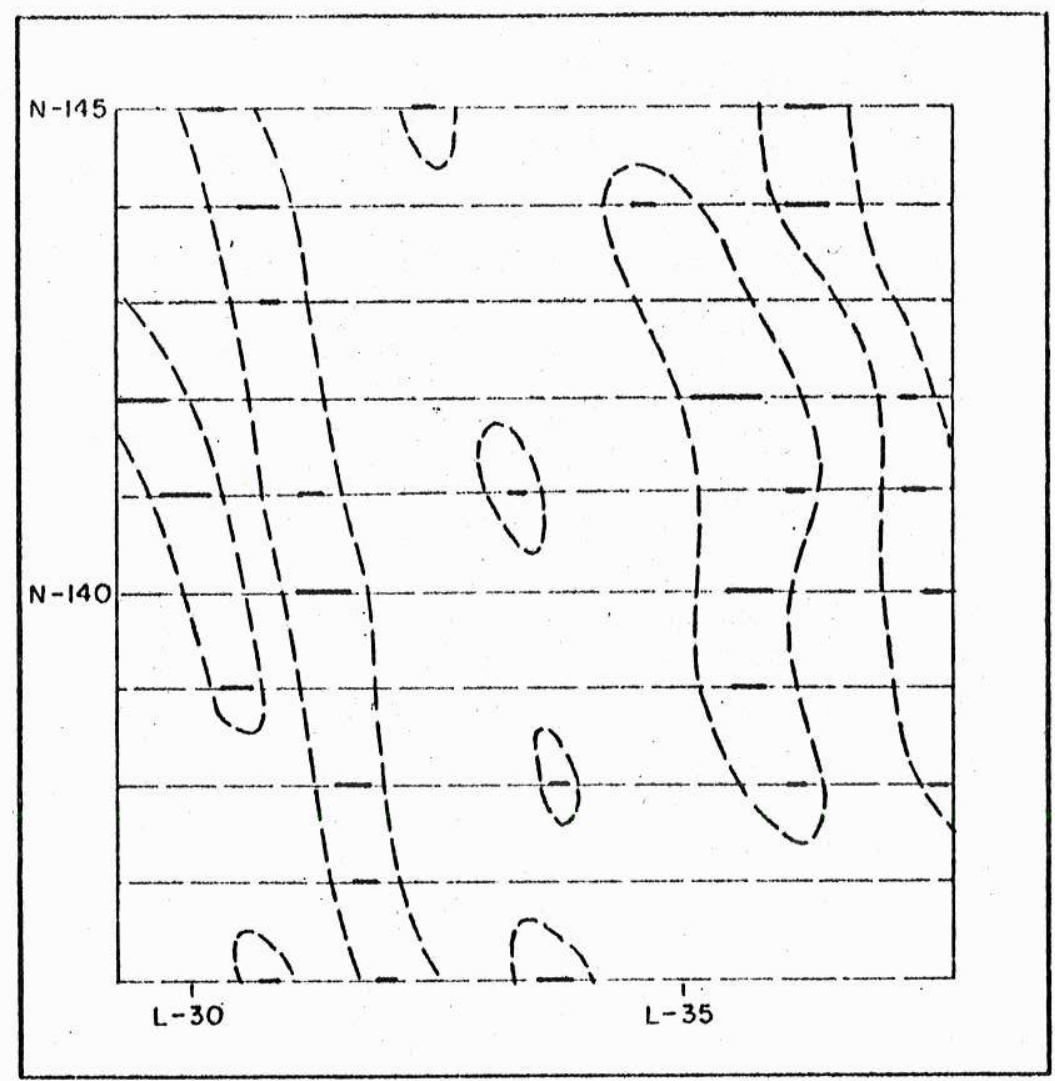

Figura 30 - Posição das anomalias geofísicas obtidas pela técnica da as sociação de resíduos. 
.90 .

\section{B.3 - CONCLUSOES}

\section{A - Laboratōrio}

a) - quanto a amplitude da anomalia

1. a amplitude da anomalia aumenta com a relação a/T, ou seja, com a diminuição da profundidade para um mesmo espaçamentoentre as bobinas.

2. a amplitude da anomalia aumenta com o aumento da frequência, em consequência do aumento do fator indutivo.

b) - quanto a forma da anomalia

1. a forma da anomalia depende da inclinação do corpo condutor. A forma da curva ē uma indicação ūtil na determinação do rü mo do mergulho do corpo.

c) - quanto a posição do corpo

1. a anomalia é māxima quando o corpo se encontra situado entre as bobinas. Quando qualquer uma das bobinas se encontra verticalmente sôbre o corpo, principalmente quando èste è vertical, os valores de I e R são respectivamente $0 \%$ e $100 \%$. 


\section{B - Mina Camaquã}

a) - conforme mostra a figura 12, minērio filonar com teor de sulfeto acima de 4\% (exemplo filão S.Luiz), provoca anomalias que po dem atingir até 40\% (pico a pico).

b) - filões com teor de sulfeto inferior a 2\%, tendo como ganga bari ta, calcedônia, quartzo e limonita, não causam anomalia quandose utiliza o equipamento E M Gun.

c) - riachos (sangas) podem provocar o aparecimento de anomalias. Pa ra se verificar se êstes são realmente as causas das anomalias, è suficiente medir-se um segundo perfil, deslocado à montante ou a juzante do ponto anteriormente medido, não ao longo da dire ção geológica local, e verificar a constância da anomalia com a presença do riacho.

d) - falhas podem provocar o aparecimento de anomalias. Perfis medidos em Camaquã confirmam a existência de uma falha, onde se encontra encaixado o Ribeirão João Dias, nas proximidades da usina de tratamento da Mina.

e) - o funcionamento de motores elétricos perturba de muito os levan tamentos nas proximidades da Mina. 


\section{C - Mina Caraíba}

a) - corpos de minério disseminado, mesmo extensos, provocam o apare cimento de anomalias geofísicas.

b) - faixas ricas em minerais māficos em rochas gnaissicas, parecemprovocar o aparecimento de anomalias geofísicas.

c) - em zonas de anomalia geoquīmica, eram encontradas anomalias geofísicas.

d) - nas proximidades das extremidades de lentes de granito róseo de grã fina, aparecem anomalias geofísicas.

e) - lentes contendo grafita provocam anomalias geofísicas.

f) - mesmo em locais sem anomalia geoquīmica, o "back-ground" geofīsico, apresenta-se bastante irregular causado provāvelmente pela concentração de minerais mäficos ou de fraturas contendo āgua salobra.

g) - o método mostra-se mais conclusivo que o do potencial induzido, sobretudo em locais de cobertura aluvionar de alta salinidade (mesmo em período de sêca).

h) - na ēpoca da sêca os trabalhos são fortemente dificultados pela alta intensidade da eletricidade estātica.

i) - concentrações de sulfetos acima de $3 \%$ provocam anomalias.

j) - rochas bāsicas e ultrabāsicas podem causar anomalias. 
1) - a técnica de "trend surface analysis" è aplicāvel quando se faz uso dos resîduos, sobretudo das superfícies de primeiro grau.

m) - para facilitar a correlação entre as anomalias de diferentes per fis, ē aconselhāvel não espaçā-los mais de $150 \mathrm{~m}$.

n) - o método demonstrou-se aplicāvel na região, porēm as anomaliasnão são provocadas exclusivamente por sulfetos de cobre. E ne cessārio haver uma perfeita correlação entre a posição das anomalias geoquỉmica e geofísica, para que se justifique o emprêgo de métodos mais caros para verificar a causa das anomalias. 
.94.

\section{B. 4 - BIBLIOGRAFIA}

Bentz, A. - Lehrbuch der Angewandten Geologie, v.I, Ferdinand Enke Verlag, Stuttgart, 1961, $1058 \mathrm{pp}$.

Caraība Mineração Metalurgia - Relatōrios. Inēditos.

Companhia Brasileira do Cobre - Relatōrios. Inéditos.

Costa Filho, J.H. - Prospecção da Mina de Cobre de Camaquã no Rio Grande do Sul, Brasil. Div. Fom. Prod. Minera1, Bol.59, parte II, p. 13-85, Rio de Janeiro, 1944.

Coutinho, J.M.V., Barros Gomes, C. - A Jazida de Cobre da Caraība, Ba: Alguns Aspectos Petrogenéticos. An.Acad.Bras.Ciên., v.36, n.3 . p. 374R-375R, Rio de Janeiro, 1964.

Cunha, A.N., Lacourt, F. - Região Cuprīfera de Caraíba e Poço de Föra (Ba hia), Brasil. Div. Fom. Prod. Mineral, Bol. 41, p.85-98, Rio de Janeiro, 1940.

Grant, F.S. \& West, G.F. - Interpretation Theory in Applied Geophysics. Mc-Graw-Hi11 Book Company, N.York, 1965, 583 pp.

Hedstron, E.J.,Parasnis, D.S. - Some Model Experiments Relating to Elec tromagnetic Prospecting With Special Reference to Airborne Work. 
.95 .

Geoph. Prosp., v. VI, nọ4, p.322-341, 1958.

Kollert, R - Electromagnetic Prospecting - Memorandum. Inédito, 1970, 14 pp.

Leinz, V., Barbosa, A.F. - A Jazida de Cobre do "Cerro dos Martins", Caçapava - Rio Grande do Sul - Min.Met. v.V, nọ3, p.252-258, 1941

Leinz, V., Almeida, S.C. - Gênese da Jazida de Cobre de "Camaquan", Municîpio de Caçapava, Rio Grande do Sul. Rio Grande do Sul, Dir. Prod. Mineral, Public. nọ4, Pôrto Alegre, 1941, 47.pp.

Leinz, V., Barbosa, A.F., Teixeira, E.A. - Mapa Geolōgico Caçapava - La vras. Rio Grande do Sul, Dir. Prod. Mineral, Public. no 6, Pôr to Alegre, $1941,39 \mathrm{pp}$.

Leinz, v. - Gênese da Jazida de Cobre da Caraíba, Baia. Min. Met. v.XII , no 72, p. 629. Rio de Janeiro, 1948.

Leonardos, 0.H. - Cobre no Estado do Rio Grande do Sul - Div. Fom. Prod.Mineral, Bol. 59, parte IV, p. 97-117, Rio de Janeiro, 1944.

Lewis Jr., R.W. - Geologia e Geoquímica da Jazida de Cobre de Caraība, Ba hia, Brasil. Div. Fom. Prod. Minera1, Bo1. 119, p. 57-58, Rio de Janeiro, 1964.

Melcher, G.C., Mau, H. - Novas Observações Geolögicas na Região de Caçapa va do Sul. An. Acad. Bras. Ciên. v.32, nọ 1, p.43-50, Rio de Janeiro, 1960. 
Me110.Jr., J.L, Pouchain, E.B. - Cobre no Estado da Bahia, Brasil. Div. Fom. Prod. Mineral, Bol.79, p. 77-78, Rio de Janeiro, 1946. Ribeiro, M., Bocchi, P.R., Figueiredo Fọ, P.M., Tessari, H. - Geologia da Quadrícula de Caçapava do Sul - Rio Grande do Sul, Brasil . Div. Fom. Prod. Mineral, Bol. 127, 1966, 232 pp.

Robertson, J.F. - Revision of the Stratigraphy and Nomenclature of Rock Units in the Caçapava - Lavras Region, State of Rio Grande do Sul. Notas e Estudos, v.I, nọ2, Escola de Geologia da UFRGS, Pōrto Alegre, 1966.

Schneider, A. - Piroxenitos Cuprīferos de Caraíba, Bahia. Min. Met. v. XV, nọ 90, p. 271,276, Rio de Janeiro, 1944.

Teixeira, E.A. - A Mina de Cobre de Camaquã. Div. Fom. Prod. Mineral,Bol. 49, 1941, $47 \mathrm{pp}$.

THrnqvist, G. - Some Practical Results of Airborne Electromagnetic Prospecting in Sweden. Geoph. Prosp. v. VI, no 2, p. 112-126, 1958.

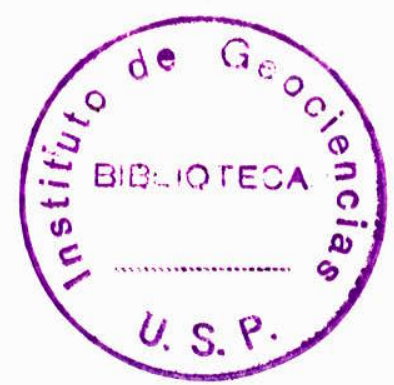

